\title{
III Literary Snapshots of the In-Between
}

"Who knows how many slaves will someday owe their freedom to the poets!" writes the Cuban Félix Tanco enthusiastically, in a letter to Domingo del Monte. The following observations support the thesis, of which Tanco's statement is the best illustration, that literature, as Edward Said says, anticipates political developments and that cultural dimensions are what make up the depths of imperialism, or may even precede political imperialism. In the light of these assumptions, this chapter responds to two main questions:

1. In my opinion, colonialism research (which continues to flourish) tends to divide its field of study into linguistic and cultural units, whereas its theorization aims to find generalizations. The colonial history of cultural and literary entanglement, in the sense of a colonial histoire croisée (the history of colonial interconnections), on the other hand, tends to be somewhat neglected. And this is exactly where the Caribbean offers an enormous potential for examining not just the hegemonic axes but also intercolonial transfers, thanks to the immediate juxtaposition of different colonial cultures. It is well-known that French nineteenth-century colonialism was far more successful than the Spanish version. Long before the loss of its last colonies in 1898 , Spain was already in a steady decline, whereas it was not until the nineteenth century that the French idea of a civilizing mission really blossomed (aside from the painful loss of Haiti, whose violent emancipation was taken as an alarm signal far beyond the French colonial sphere). On the political level, France's cultural gravitational force proved to be long-lasting: the French Antilles remained a part of the mother country and became overseas departments in 1946. I would like to take these rough findings as a starting point for asking in what ways the literary texts of the Spanish and French Caribbean anticipate political developments. What can they contribute to an examination of a colonial histoire croisée? And very specifically: does the literary production of the French and Spanish Caribbean offer us indications of the perpetuation of the French model and the decline of the Spanish one? I will focus here on how the literature positions itself with respect to colonialism, primarily in terms of the two main themes of the nineteenth-century Caribbean, namely independence and abolition.

2. I will be looking primarily at literary transfer processes within, into, and out of the Caribbean, which have been relatively neglected until now. This involves both extraliterary and intra-literary dimensions. Which transfers are staged how? Or: which versions of reception, appropriation, and transformation have taken which paths? 
I do not by any means propose to consider the two constellations of questions in isolation from each other; the interconnections between, on the one hand, the scope, character, and range of the transfer and, on the other, the political and cultural positioning are precisely what interest me.

Transfer processes are multidimensional, whether in the framework of investigations of the festival as a basic anthropological constant and site of transculturation, or in the context of a history of harbors, seen as inherent meeting places. There are also, of course, important transfers that take place within the circulation of ideas, for our purposes in particular very often in reference to the various ways in which the Haitian Revolution is transmitted. Further examples could include traveling theater groups (Reinstädler, Theatralisierung), immigration policies that emphasize whiteness out of fear of Africanization (cf. Naranjo Orovio; Chinea), ${ }^{1}$ and carriers of subversive knowledge, such as pirates, as the protagonists of an early version of globalization from the bottom up (cf. Arnold). What all of these investigations (which I believe are very valuable) have in common is that they look away from static comparative models towards forms of exchange and new forms of movement that have so far been underestimated.

In the following expositions, we will be dealing with literary snapshots of an in-between; I consciously refrain from typologizing them and instead use them to try to capture a multiplicity of aspects. The time period under consideration, 1789 to 1886 , is one that, for the Caribbean in particular, consolidates the results of the second phase of accelerated globalization; ${ }^{2}$ on the literary level, all of the

1 Naranjo Orovio shows the kinds of fearful reactions that were unleashed on the neighboring island of Cuba by the Haitian Revolution and its upheavals. Naranjo Orovio addresses the "ghost of barbarism," a fear legend that the Spanish colonial authorities and the local elites nourished and used to fortify Spain's colonial preeminence in Cuba and Puerto Rico through the end of the nineteenth century. The well-established concepts of civilization and barbarism, and their inversion in Haiti's case, played an important role here. Cf. also Abel, "Tagungsbericht" 476. Chinea shows how the fear and anxiety of the slave owners, provoked by the immigration and the presence of Free People of Color coming from the Caribbean to Puerto Rico, led to racist laws.

2 The dynamics of globalization in the nineteenth century are particularly intense around the connection between globalization and the civilizing mission. In the early modern period there did not yet exist the conviction that European civilization was the only civilization worthy of the name; this globalization of civilizational norms was new in the long nineteenth century and presumed that older balances, whether military, economic, or cultural, between Europe and the other continents, had been disrupted. The successes of the nineteenth century's civilizing missions were based on two further preconditions as well: first, the conviction (not just on the part of the representatives of the European power elites but also on the part of private agents of globalization of many different kinds) that the world would be a better place if as many nonEuropeans as possible were to adopt the accomplishments of the superior civilization; and sec- 
authors presented here are committed to the ideal of romantic writing. Insofar as we think of time and space together, in the history of movement that derives from their combination, and focus primarily on the transfer and translation of knowledge, we will be looking at "thinking about globality as the archeology of its mobility" (to use Ottmar Ette's words about Alexander von Humboldt) (Ette, Alexander von Humboldt 92). ${ }^{3}$

In both of the colonial empires, this is a time of overlaps in which, as far as colonial dependence is concerned, the colonial status quo is maintained, with the sole exception of the island of Hispaniola. The year 1848 marks an important dividing line, when slavery is abolished in the French colonial empire. Because of that, the texts are grouped around an event that radically changed the societies or, in the case of the Spanish colonies, made the question of abolition even more pressing because of what was happening in their immediate surroundings. Almost all of the textual examples are the literary testimonies of the writing Creole upper class, which, although it does not come anywhere near to reflecting the "holistic condition" of a society, is nevertheless alone responsible, in a decisive way, for the establishment of the prevailing discourses and is therefore writing an écriture blanche (cf. Bremer 336). However, this does not mean that this is the gaze of "imperial eyes" (cf. Pratt).

\section{III.1 The Creole Upper Class}

Creole writing was the expression of a permanent in-between-ness, an inner rift, that could on the one hand have very destructive effects, keeping the writer rigidly stuck in conservative thought patterns, but could also, on the other hand, be highly productive. ${ }^{4}$ The very term "Creole" is already very difficult to define. The following examples come from the pens of Euro-Creoles, that is to say representatives of the white upper class who were born in the Antilles and stayed in constant contact with the metropolises of their respective mother countrys. The difficulty of establishing any clear position often manifests itself in a particularly fraught struggle by this colonial class for the confidence that they are compatible

ond, the appearance of social forces at the numerous peripheries that shared this view as well. Cf. Osterhammel $911 \mathrm{ff}$.

3 "Denken der Globalität als Archäologie ihrer Mobilität."

4 It has never been possible-even before the nineteenth century or in parts of the world other than the Caribbean-to write a history of the Creoles from one central perspective, and definitely not according to the European pattern of a "total, panoramically illuminating, central perspective.” Cf. Ette, ZusammenLebensWissen 17. 
with the elite of the center. Thus the thriving theater life in Saint-Pierre, then the capital of Martinique, is described as follows in Prévost de Sansac de Traversay's Les amours de Zémédare et Carina (The Loves of Zémédare and Carina) (1806) ${ }^{5}$ :

Saint-Pierre was the only city in Martinique that had a theater. Troupes would come from Paris every year to put on shows there. And these shows were usually good, because the public was knowledgeable and sometimes quite demanding, especially in matters of singing or music. $(8)^{6}$

Prévost de Sansac's description of the inhabitants of what he calls the richest French colony of the time is similar:

Martinique, one of the windward islands in the American archipelago, is today the most flourishing and most precious of France's colonies. The richness of its soil, the beauty of its climate, and its cleanliness make it worthy to be inhabited by the most generous, the most affable, and the best of men. The Martinicans, who are naturally spiritual, loyal, loving, and in general well-made, are all valiant. There are few countries where one sees a larger number, proportionally speaking, of pretty women. $(21)^{7}$

Mr. Saimprale, one of the main characters in Les amours de Zémédare et Carina, has never been to Europe. But the narrator immediately attempts to defuse this "deficit" by referring to his excellent education: "Mr. Saimprale had never been to Europe; nevertheless, the care that his father had taken with his education put him on a level with men who were considered to be of the best society. His morals were tender, his face pleasant" $(25){ }^{8}$ Behind such descriptions there lurks the idea that the Creole upper class should be described in a thoroughly positive

5 Corzani (II:301) describes Les amours de Zémédare et Carina as the first novel about Martinique by a Martinican writer.

6 "Saint-Pierre était la seule ville de la Martinique à posséder un théâtre. Des troupes venaient, chaque année, de Paris, y donner des spectacles. Et ces spectacles étaient généralement de qualité, car le public était connaisseur, et il se montrait parfois exigeant, surtout quand il s'agissait de chant ou de musique."

7 "La Martinique, une des îles du vent de l'archipel américain, est aujourd'hui la colonie la plus florissante et la plus précieuse de celles que la France possède. La richesse de son sol, la beauté de son climat et sa salubrité, la rendent bien digne d'être habitée par les plus généreux, les plus affables et les meilleurs des hommes. Les Martiniquais, naturellement spirituels, fidèles, aimants, en général bien faits, sont tous braves. Il est peu de pays où l'on voie, proportion gardée, un plus grand nombre de jolies femmes."

8 “M. Saimprale n'avait jamais été en Europe; cependant le soin que son père avait pris de son éducation le mettait de pair avec les hommes réputés pour être de la meilleure société. Ses mœurs étaient douces, sa figure agréable.” 
way. Les amours de Zémédare et Carina is a colonial pro-slavery novel. It develops the picture of a Creole slave owner who is primarily a protector:

The fair master is always well served by his slaves, esteemed by his compatriots, and protected by the government. The cruel master ... there isn't any among the white men on Martinique; looked on with horror by all, he would soon be forced to leave the island. Without trying to justify slavery here, I simply observe that the world's earliest records speak of its existence: we have seen it persist across all the centuries, and even in Sparta, the most republican of all governments. It has never been possible to successfully entrust the cultivation of the soil in the tropics to white men; they cannot endure this arduous work. The Negroes, all across the vast expanse of the coast of Africa, only use their freedom to satisfy their stupid ferocity, to make war on each other, to destroy and devour each other. In our colonies, in contrast, see their gaiety, their pleasures, and the moderation of their work; they are without worries for the future; they know love and can freely enjoy the happiness of being fathers. ... Laborers of Europe, ... and you especially, you serfs attached to the land in Poland and in Russia; you whom we so often see anxious about your existence and that of your family: tell us whether the Negroes in the colonies are the unhappiest beings on earth. $(61)^{9}$

It is characteristic of the Creole upper class's orientation towards France that they always keep one foot in the mother country: "We shall not transport our fortune there, because it may well be that one day some of our children, or even we ourselves, will be very glad to find it again in France" (183). ${ }^{10}$

In J. Levilloux's novel Les créoles ou la Vie aux Antilles (The Creoles or Life in the Antilles), ${ }^{11}$ France is consistently glorified as a colonial power and a site of education. The reason for Estève being sent to France is clearly articulated: "his

9 "Le maître juste est toujours bien servi par ses esclaves, estimé de ses compatriotes et protégé par le gouvernement. Le maître inhumain ... il n'en existe point parmi les hommes blancs, à la Martinique, vu avec horreur par tous, on le forcerait bientôt à sortir de l'île. Sans vouloir chercher à justifier ici l'esclavage, j'observai seulement que les premiers annales du monde parlent de son existence: on l'a vue se maintenir dans tous les siècles, et même à Sparte, le plus républicain de tous les gouvernements. La culture des terres, entre les tropiques, n'a jamais pu être confiée, avec succès, à des hommes blancs; ils n’y peuvent résister à ce travail pénible. Les nègres, dans toutes la vaste étendue de la côte d'Afrique, n'usent de leur liberté que pour assouvir leur stupide férocité, se faire la guerre, se détruire et se dévorer entr'eux. Dans nos colonies, au contraire, voyez leur gaîté, leurs plaisirs et la modération de leur travail; ils sont sans souci sur l'avenir; ils connaissent l'amour, et jouissent librement du bonheur d'être pères. ... Journaliers d'Europe, ... et vous surtout, serfs attachés à la glèbe en Pologne et en Russie; vous que l'on voit si souvent inquiets sur votre existence et sur celle de votre famille, dites-nous si les nègres, dans les colonies, sont les êtres les plus malheureux sur la terre.”

10 "Nous n'y transporterons point notre fortune, parce qu'il est possible que quelques-uns de nos enfants et peut-être nous-mêmes, nous soyons très aises un jour de la retrouver en France." 11 For a short summary of the novel please see section II.1.3.2. 
father, a planter in Guadeloupe, had sent his son to France when he was very young to draw from the beautiful knowledge that at that time was rarely to be found in the colonies" (20). ${ }^{12}$ Just before the two protagonists return to Guadeloupe from Paris, Edmond (a white Creole) reassures Estève (who is mulatto), telling him that it is still too early for them to worry about the survival of their friendship: "We are still in France, let us take advantage of the equality that we are fortunate enough to enjoy here. On the other side of the ocean our friendship, even in its embarrassment, will draw the means to sustain itself without exciting the scandal of color-based prejudice" (32). ${ }^{13}$ Meanwhile, Edmond's sister Lea is particularly excited about her brother's return because he will be bringing her news from the metropolis:

She impatiently awaited the return of her brother Edmond, who was bringing her seductive accounts of the marvels of Paris and whose science, enlarged by her naive imagination, would reveal to her a multitude of secrets that only a young man raised in Europe could know. $(38)^{14}$

Les amours de Zémédare et Carina refers to two academies on Martinique, not exactly offering an equivalent option to the fixation on Paris's educational institutions but at least presenting an alternative solution on the island:

If this boarding school and Saint Victor's Academy, which have already rendered the greatest services to this colony, were to cease to exist, it would be an incalculable loss for all the inhabitants of Martinique and of the neighboring islands who are not wealthy enough to send their children to France to be raised there, or who do not want to send them there until they are of a certain age, and to perfect their earlier education. It is, if I dare say so, in the interest and the duty of the government to devote all its care to preserving these two important establishments. (Prévost de Sansac 142) ${ }^{15}$

12 "son père, planteur à la Guadeloupe, avait envoyé son fils, jeune, en France, y puiser ces belles connaissances qui, à cette époque, se rencontraient rarement aux colonies."

13 "Nous sommes encore en France, profitons de l'égalité dont on a le bonheur d'y jouir. Audelà de l'Océan notre amitié puisera dans sa gêne même les moyens de s'entretenir sans exciter le scandale des préjugés de couleur."

14 "Elle attendait avec impatience le retour de son frère Edmond qui lui apportait de séduisans récits sur les merveilles de Paris, et dont la science agrandie dans sa naïve imagination lui révélait une foule de secrets que pouvait seul connaître un jeune homme élevé en Europe.”

15 "Si cette pension et le collège de Saint-Victor, qui ont déjà rendu les plus grands services à cette colonie, cessaient d'y exister, ce serait une perte inappréciable pour tous les habitants de la Martinique et ceux des îles voisines, qui n'ont pas assez de fortune pour envoyer leurs enfants en France pour y être élevés, ou qui ne veulent les y envoyer qu'à un certain âge et pour y perfectionner leur première éducation. Il est j'ose le dire, de l'intérêt et du devoir du gouvernement d'apporter tous ses soins à la conservation de ces deux établissements importants." 
In spite of all of the glorification of the metropolis, however, the colonies themselves also serve as models for the future, even appearing as sites for utopias: "People felt the old world crumbling beneath their feet and were already throwing themselves towards that future, so near, where a new society was to be rebuilt" (Levilloux 21). ${ }^{16}$ The political environment of the July Monarchy seemed favorable for an imminent abolition of slavery, which brought up urgent fears of loss among the plantation-owning oligarchy. In the eighteen-thirties, people were reminded of the runup to 1789. The loss of the ancien régime still haunted the writers of the Creole upper class.

Reading Maynard de Queilhe's 1835 novel Outre-mer, one gets the sense of a society that is stuck, a Creole caste driven by fear of losing its old privileges. Two of the protagonists have the author's particular sympathy: Mme de Château, who brings the news of the trois glorieuses (the three glorious days of July 26 through 28,1830 ) and who wears a black dress that she never takes off anymore; and the Marquis de Longuefort, who says "The people of France are a horrible people" (Maynard de Queilhe II:178, 183). ${ }^{17}$ The utterances of Marius, the mulatto, seem to be written into a discourse of dissension. After his studies in France he curses Martinique, the island of his origins:

A miserable little island! Less than an island, a kind of islet; fevers, snakes, and beings that give themselves lashes of the whip because they are not equally yellow, or because some of them are too much so and others not enough; or maybe because there are some of them who are not yellow at all. Misery! Miseries! (I:42) ${ }^{18}$

The narrators of the two novels Outre-mer and Les créoles evaluate the fixation on France and the rejection of the colonial homeland by their respective mulatto heroes in entirely different ways, however. Marius reproduces the slogans of equality that he has picked up in the mother country and gets worked up about the racial mania of his country of origin, only to gradually realize, after his return, how unrealistic the egalitarian ideas of the French Revolution are and how thoroughly they miss the point of the colonial reality and the actual inequality and unequal value of people of differing skin colors and origins. In a

16 "Les hommes sentaient le vieux monde s'abîmer sous leur pieds et se jetaient déjà vers cet avenir si prochain où devait se reconstruire une nouvelle société."

17 "C'est un affreux peuple que ce peuple de France."

18 "Une misérable petite île! moins qu'une île, une espèce d'îlet; des fièvres, des serpents et des êtres qui se donnent des coups de fouet, parce qu'ils ne sont pas tous également jaunes, ou parce que les uns le sont trop et les autre pas assez; ou parce qu'il y en a qui ne le sont pas du tout. Misère! misères!” 
process of refinement, along the lines of a classical bildungsroman, he laboriously discovers that the philanthropic ideas that come out of certain circles in Paris and London unfairly discredit the well-established plantation system.

The fate of Levilloux's mulatto protagonist, Estève, on the other hand, is tragic, not just because the societal barriers mean that he cannot live out his love for his white friend's sister but because, in his fruitless attempts to gain recognition in white Creole society, he also enrolls in the fight against the rebellious black slaves. In order to be whiter than the whites, he allows himself to be yoked into the active exclusion of those who are racially even lower than he is, instead of seeking solidarity with them; he participates in the suppression of one of the numerous rebellions of the black slaves. While Estève's hymn of love to the mother country is enduring, and is able to withstand the repugnant and antiegalitarian reality of the colony, for Marius the "achievements" of the mother country prove to be nothing more than hot air. It is not that the colony is hobbling after the mother country in vain, but that the ideas of the mother country have not caught up with reality and with the specific experiences of the conviviality of various races in the colonies. The revolution's castles in the air, which ultimately turn out to be foolish, seriously threaten the status quo, represented as a paradise.

The Creole upper class is a population group that is in a genuinely in-between space, even if this brokenness and turmoil manifests itself in very different ways.

\section{III.2 The Conceptual Inadequacy of the Terms patrie/Nation/Exile}

What the literary texts of the French and Spanish Caribbean have in common is that the attributions of nation, patrie, and exile are not always able to work unambiguously. The writing Creole upper class was in a permanent state of in-between-ness. In the valuable paratext of his foreword to Outre-mer, Maynard de Queilhe describes the self-understanding of the Creoles as exiled French people, ready at any moment to return home to the "old father country" (I:13): in other words, the colonies are just a way station. The novel itself is clearly marked: it is signed by a "Frenchman from America." Maynard de Queilhe himself is living an exile experience in the Antilles, characterized by longing for the mother country.

On an intra-literary level, it is telling for our line of questioning that with his hero, the mulatto Marius, Maynard de Queilhe transfers a particular kind of exile experience, one that is symptomatic for the new competitors of the Békés: that of the class of free people of color, a class that first began its social rise in 1830 and 
has almost the same rights as whites do. This new class is homeless, which means that precisely because of its homelessness, it can freely choose its new spiritual home. And what it has chosen as its patrie is not France, but England. No wonder, especially since slavery has long since been abolished in the British colonial empire and the mulattos, too, already had other rights (I:43).

In Levilloux's work, France always represents a clear point of reference, for instance when the principal introduces Edmond Briolan as a new student. The colony is “le pays,” “the country”: “"My children,' says the principal, 'I present a new classmate to you. His country is far away, and being alone in France now, he will need your friendship"” (Levilloux 20). ${ }^{19}$ A return to the island of Guadeloupe, however, means a return to the patrie: "We are returning to our fatherland [patrie], but at least we know the obstacles that our affection will have to overcome" (21). ${ }^{20}$ On the other hand, from the moment that Briolan and Estève leave the French mainland, they are "exiles." More than that, they are like travelers heading off into the desert:

\begin{abstract}
Thus our young exiles took away with them in their hearts an entire France of emotions, of memories, and of consoling thoughts for the hours of bitterness. In this they were like travelers leaving for the desert who put their hopes of salvation in the abundance of their supplies. But the fires of the sun will dry up their wineskins, the impure insects will taint their fruits and meats; and the unhappy travelers, instead of being able to draw life from them, will find there only disgust and more regrets. $(32)^{21}$
\end{abstract}

While on the one hand their absence from Paris is described as an exile, the Caribbean also appears, on the other hand, as a place of longing, and the thought of an exile is always present when Edmond's and Estève's native region is discussed:

19 "Mes enfants, dit le recteur, je vous présente un nouveau camarade. Son pays est éloigné, et bientôt seul en France, il aura besoin de votre amitié."

20 "Nous retournons dans notre patrie, mais nous connaissons du moins les obstacles que notre affection aura à surmonter.”

21 "Ainsi nos jeunes exilés emportaient dans leur cœur toute une France d'émotions, de souvenirs et de consolantes pensées pour les heures d'amertume. En cela, semblables aux voyageurs partant pour le désert, et qui mettent leurs espérances de salut dans l'abondance de provisions. Mais les feux du soleil dessècheront leurs outres, les insectes impurs corrompront leurs fruits et leurs viandes; et les malheureux, au lieu d'y puiser la vie trouveront que dégoût et surcroît de regres." 
Martinique sketches its fertile shores in front of my eyes ... but in the middle of my emotions a bitter thought cuts across my soul, and I avert my gaze to turn it towards this land of exile. $(201)^{22}$

Weary of the land of exile, not knowing where to lay his head, which no longer slept. ... I cannot die in exile. $(208)^{23}$

The concept of the "nation" is also used in an interesting way here. In Les créoles ou la Vie aux Antilles, for instance, the black population groups are referred to as nations: "He had barely pronounced the first words when some Bambaras, a nation that was an enemy to his ..." (116). ${ }^{24}$ The term is also used similarly in Les amours de Zémédare et Carina: the variety in physiognomy of the black population is traced back to their differing African ethnicities, which the narrator refers to as nations:

The European can barely distinguish one Negro from another, they all look equally black to him; all he sees are flat noses, thick lips, and kinky hair. But the Creole, used to living with them, can not only distinguish the individuals among them, he will also be able to tell you at first glance to which nation he belongs. The Mocos have teeth separated into festoons. ... The Calvaire Negro is distinguished from all others by the perfect blackness of his skin as well as by the beauty of his contours; it is from among those of this nation that the sculptor and the painter should choose their models. On Sundays and holidays, the most genuine gaiety reigned throughout the establishment; the Negroes and Negresses of the neighboring dwellings came to add to the pleasures with their presence. They separated out by nations, thus forming that many different groups, and each one had its own particular dance. (Prévost de Sansac 62) ${ }^{25}$

22 "La Martinique dessine ses fertiles rivages devant mes yeux ... mais au milieu de mes émotions une amère pensée traverse mon âme, et je détourne les regards pour les porter sur cette terre de l'exil."

23 "Fatigué de la terre de l'exil, ne sachant où reposer sa tête qui ne dormait plus. ... Je ne peux mourir dans l'exil."

24 "A peine avait-il prononcé les premiers mots que des Bambaras, nation ennemie de la sienne ..."

25 "L'Européen sait à peine distinguer un nègre d'un autre, tous lui paraissent également noirs; il ne voit que des nez plats, de grosses lèvres et des cheveux crépus. Mais le créole, habitué à vivre avec eux, distingue non seulement les individus entr'eux, il vous dira même, à la première vue, à quelle nation il appartient. Les Mocos ont les dents séparées en feston. ... Le nègre Calvaire se distingue parmi tous les autres par la noirceur parfaite de sa peau, ainsi que par la beauté de ses formes; c'est parmi ceux de cette nation, que le sculpteur et le peintre doivent choisir leurs modèles. Les dimanches, et les jours de fête, la gaîté la plus vraie régnait dans tout l'atelier: les nègres et les négresses des habitations voisines venaient, par leur présence, ajouter aux plaisirs. Ils se divisaient par nations, et formaient autant de groupes différents, et chacun avait sa danse particulière." 
A look at a representative example from the Spanish Caribbean, on the other hand, shows that questions of exile are negotiated differently there. Thus, they do not play any explicit role in the novel Sab. They are, however, translated to the slaves themselves in a further sense:

\begin{abstract}
Nor do I have a homeland to defend, because slaves have no homeland; I have no duties to carry out, because the duties of the slave are the duties of the beast of burden that walks as long as it can and lies down when it can no longer walk. If at least the white men, who cast out of their societies anyone who is born with a differently colored complexion, would leave him in peace in their forests, then he would have a homeland and loves there. (Gómez de Avellaneda, Sab ed. Servera 36 ${ }^{26}$
\end{abstract}

What is also revealing in Gómez de Avellaneda, for the question of possibilities of expression from exile, is that she rescinds her authorship to a certain extent when she integrates her writing process into the novel itself and ascribes it to her male protagonist. Towards the end of the novel, it becomes clear that the entire narrative is a farewell letter from Sab, a slave and the eponymous hero. This has two results: first, it gives an authoritative (authorial) voice to the hero of the novel, who is ethnically and socially more or less excluded, and that voice lifts and transforms him from a colonial object into not only the subject of his own story, but also the subject of his own discourse; second, it moves the narrative word from far away (Madrid) into the scene of the novel, thus somewhat moderating the perceived illegitimacy of a statement coming from the outside (and from the land of the colonizers).

Let us stay with this author and turn our attention to a dimension outside the narrative: in 1859, after a twenty-three-year stay in Spain, she came "back" to Cuba for the first time in all that time, and her reception by Cuban intellectuals was ambivalent. In literary circles, the question of her national affiliation sparked a lively debate, called "The Avellaneda Question.” Thus, in a newspaper article from the Aurora del Yumurí, dated August 27, 1867, we read:

The "Areopagus" literary club, meeting in Havana to choose which compositions are worthy of being included in the book "The Cuban Lyre," has determined to exclude the poetess Mrs. Gertrudis Gómez de Avellaneda, considering her to be not Cuban but from Madrid. On

26 "No tengo tampoco una patria que defender, porque los esclavos no tienen patria; no tengo deberes que cumplir, porque los deberes del esclavo son los deberes de la bestia de carga que anda mientras puede y se echa cuando ya no puede más. Si al menos los hombres blancos, que desechan de sus sociedades al que nació teñida la tez de un color diferente, le dejasen tranquilo en sus bosques, allá tendrán patria y amores.” 
the other hand, it seems that Mr. Saturnino Martínez and Mr. Antonio Enrique de Zafra will from now on be regarded as Cuban writers. (Gómez de Avellaneda, Cartas 62) ${ }^{27}$

\section{A few months later (January 15, 1868), a completely different opinion appears in the same newspaper:}

Junta - The literary club of our high school met last night, at the request of one of its members, to deal with the Avellaneda question. We were not able to attend this meeting, but we are informed that it was agreed that the literary club considers Mrs. Gertrudis Gomez de Avellaneda to be one of the literary glories of which Cuba can be proud, and it was also agreed to prepare a certificate of this resolution for appropriate purposes. (62ff.) $)^{28}$

Whether the author belongs to Cuba or to Spain is decided arbitrarily and strategically, case by case.

27 "El Areópago literario reunido en la Habana para escojer las composiciones dignas de figurar en el libro, 'La Lira Cubana', ha determinado escluir a la poetisa Sra. $\mathrm{D}^{\mathrm{a}}$ Gertrudis Gómez de Avellaneda, por no considerarla cubana sino madrileña. En cambio, parece que los Sres. D. Saturnino Martínez y D. Antonio Enrique de Zafra serán mirados en lo adelante como escritores cubanos."

28 "Junta - La Sección de Literatura de nuestro Liceo celebró anoche, a petición de uno de sus miembros, para ocuparse de la cuestión Avellaneda. No pudimos asistir a esa reunión, pero nos informan que en ella quedó acordado que la Sección literaria considera a $\mathrm{D}^{\mathrm{a}}$ Gertrudis Gómez de Avellaneda como una de las glorias literarias de que puede Cuba enorgullecerse, y se convino igualmente estender una acta certificada de esa resolución para los fines oportunos.” The Spanish literary critic Bravo Villasante, commenting on an 1859 correspondence, remarked that: "Her situation in Cuba is both gratifying and thankless at the same time, involving both praise and reproaches, and her double situation, being both Cuban and Spanish, is ambiguous. The fact that she arrived as the partner of a representative of the Central Government can be uncomfortable for the revolutionaries, who are working towards Cuban independence, although it might be premature. She is intelligent, notices everything, and debates the alternatives that are presented to her. In terms of politics, she loves the people and at the same time reveres His Majesty; she feels like a child of Cuba and of Spain at the same time and when they wanted to leave her out of an anthology of Cuban poets she was offended, even though also does not relinquish the glory of belonging to Spanish literature." ("Su situación en Cuba es grata e ingrata a la vez, al homenaje se une el reproche, y su doble aspecto de cubana y española es equívoco. Su llegada como consorte de un representante del Gobierno Central puede resultar molesto a los ojos de los revolucionarios, que intentan la independencia de Cuba, aunque sea prematura. Ella, inteligente, se da cuenta de todo, y se debate en las alternativas que se le presentan. Políticamente ama al pueblo, y al mismo tiempo reverencia a su majestad; se siente hija de Cuba y de España a la vez y cuando intentan de dejarla fuera de una antología de poetas cubanos se siente ofendida, aunque no renuncia tampoco a su gloria de pertenecer a la literatura española.") (cited in Servera 38). 
For the texts of both the French and the Spanish colonial spheres, we can say that the categories of nation, exile, and patrie cannot be used according to clearly delineated criteria but adapt themselves, instead, to the particular situation. This shows a kind of fragility in the concept of the nation that is not what we would have expected for that time period.

\section{III.2.1 “A Writer from Cuba is Not Always a Cuban Writer”: The Countess of Merlin}

“A writer from Cuba is not always a Cuban writer" (Díaz 58). ${ }^{29}$ These introductory words of Roberto Ignacio Díaz's about the Countess of Merlin (which are just as valid for Gómez de Avellaneda, discussed above), point to the central issue with which any discussion of the countess, a writer and musician who was born in Cuba in 1789 and died in Paris in 1852, has to grapple. Even deciding which version of her name to use presents difficulties: María de las Mercedes Santa Cruz y Montalvo is better known as Condesa de Merlín, but also Comtesse Merlin (Díaz 58; Abel, "Viajes corporales"). She writes in French, and she is a woman. This may well explain her absence from the official literary canon of nineteenth-century Cuban literature.

Shortly after she was born, her family emigrated to Madrid, but she spent the first twelve years of her life in Cuba with her grandmother. In 1802, during the French occupation of Madrid, her forward-looking mother married her off to the Count Antoine Christophe Merlin (1771-1839), a general in Bonaparte's army (Méndez Rodenas, “Journey” 708). Because they were French, the Merlins were forced to leave Spain in 1812, after Bonaparte's defeat. Between 1813 and 1839, the young Creole Santa Cruz y Montalvo became one of the leading belles dames of Paris's cultural establishments. Her salon at no. 40, rue de Bondy attracted important musicians and writers of the time. After 38 years in France, and exactly one year after the death of her husband, she returned to Cuba in 1840 for seven weeks. In 1844 she published La Havane, a travelogue based on that visit (in three volumes and a thousand pages) that is committed to romantic ideals (cf. Díaz 57). But the work constantly breaks the boundaries of the genre. The text consists of 36 letters, most of which are addressed to the author's daughter, Madame Gentien de Dissay, but some of them are addressed to a series of important European personalities: René de Chateaubriand, Prince Frederick of Prussia, George Sand, and Baron Rothschild.

29 "Una cubana escritora no es siempre una escritora cubana." 
After her Atlantic crossing on her way to Cuba, her first stops were New York and other cities on the East Coast of the United States. The Countess of Merlin's comments on the United States are characterized by the clarity of her own selfunderstanding as a foreigner: her lack of involvement in the world that she describes is plain to see. From the moment when she disembarks in New York, she describes herself as a "stranger to everything around me" (Condesa de Merlin, La Havane I:65). ${ }^{30}$ Her apparently neutral outsider position is further reinforced by statements such as "One has to see this nation in order to form an idea of its mores" (I:118). ${ }^{31}$

When she arrives in Cuba, this attitude changes immediately: now she wants to present herself to the reader as a Cuban who is describing her own familiar country. In her foreword, addressed to the captain-general, she writes: "Allow me, general, to place this work, conceived by a woman's patriotic feeling, under your protective auspices; it was inspired solely by the ardent desire to see my country happy" (I:5). ${ }^{32}$ The book is dedicated "To my compatriots" (I:7). This struggle to be recognized as Cuban is a common thread running through the text, so insistent as to be almost overpowering. Where and how can we see this? In her descriptions of the island, the author's references to the sixteenth-century Spanish "Chronicles of the Indies" are omnipresent, and overtly so. She very often mentions the chroniclers, foremost among them Columbus himself, as a direct source. ${ }^{33}$ Right at the beginning, she paraphrases Columbus's Diario de a bordo; like her, he believed he had now encountered the most beautiful country in the world when he arrived in Cuba. In more than one place she uses his descriptions of it as an idyllic sanctuary. This focus also manifests itself in her stylized portrayal of the indigenous population, which in actuality no longer exists on the island but which she depicts in very effusive language (cf. Díaz 62):

Some distance away, and closer to the coast, I come upon the village of Puerto Escondido: from those conical cottages, covered with palm branches all the way down to the ground; from the bushy banana trees whose large leaves protect the houses from the heat of the sun; from these canoes moored along the shoreline; and from the silent quietude of the

30 "étrangère à [...] tout ce qui m'entoure."

31 "Il faut voir cette nation pour se faire une idée de ses mœurs."

32 "Permettez, general, que je place sous votre égide protectrice cette œuvre conçue par le sentiment patriotique d'une femme, le désir ardent de voir mon pays heureux, l'a seul inspirée." 33 On the Countess of Merlin's constant reliance on outside sources (in one case, actually revealed as plagiarism), Silvia Molloy writes: "Rediscovery came to her less from what she saw on that trip than from what she read, remembered and imagined" (93). Cf. also Ianes 214. 
noon hour, you would say that these beaches are still inhabited by Indians. (Condesa de Merlin, La Havane I:276) $)^{34}$

In general, discovery and conquest are the Countess of Merlin's central themes. Her descriptions of nature are a particularly striking expression of an interpretation of the Caribbean as a predestined site for the symptomatic triad of "finding -inventing-experiencing” (cf. Ette, ZusammenLebensWissen 32).

When I perceive these age-old palm trees, which bend their proud foliage right down to the edge of the sea, I feel as though I am seeing the shadows of those great warriors, those men of resolution and will, the companions of Columbus and Velazquez; I see them, proud of their most wonderful discoveries, bowing down in their gratitude in front of the Ocean to thank it for such a magnificent gift. (Condesa de Merlín, La Havane I:269) ${ }^{35}$

34 "À quelque distance, et plus prêt de la côte, je découvre le village de Puerto Escondido; à ces chaumières de forme conique, couvertes jusqu'à terre de branches de palmiers; aux buissons touffus de bananiers qui, de leurs larges feuilles, protègent les maisons contre les ardeurs du soleil; à ces pirogues amarrées sur le rivage, et à la quiétude silencieuse de l'heure de midi, vous diriez que ces plages sont encore habitées par des Indiens.”

35 "Lorsque j'aperçois ces palmiers séculaires, qui courbent leur orgueilleux feuillage jusqu'au bord de la mer, je crois voir les ombres de ces grands guerriers, de ces hommes de résolution et de volonté, compagnons de Colomb et de Vélazquez; je les vis, fiers de leurs plus belles découvertes, s'incliner dans leurs reconnaissance devant l'Océan, pour le remercier d'un si magnifique présent." Cf. Díaz 64. In referring to a new reading of La Havane based on this triad, however, I want to warn against the danger of reducing Ette's concept to a way of interpreting individual passages in the text. In fact, on the contrary, the reference is intended to provide a graphic example of how to appreciate a literary text on its own merits, in an unbiased way, that might otherwise most obviously provoke ironic interpretations. The conceptual orientation of the triad finding-inventing-experiencing is etched into the fundamental redefinition of the concept of literature as possessing an overarching character rather than simply being something with which to enrich the interpretation of individual textual passages: "being open to a triangular relationship of terminologies could be the key to breaking out of the simplistic opposition between 'reality' and 'fiction,' between 'facticity' and 'fictionality,' and to gain a more complex (and simultaneously more dynamic) insight into historic, cultural, or literary processes such as those that, in the sphere of the Caribbean, ... positively force us into an investigation of the relationality between the found, the invented, and the experienced." ("In der Öffnung auf eine terminologische Dreiecksbeziehung könnte der Schlüssel zur Lösung einer Problemstellung liegen, die darauf abzielt, aus der simplistischen Gegenüberstellung von 'Realität' und 'Fiktion', von 'Faktizität' und 'Fiktionalität' auszubrechen und eine komplexere (und zugleich dynamischere) Einsicht in ebenso historische wie kulturelle oder literarische Prozesse zu gewinnen, wie sie gerade auch im Bereich der Karibik [...] zu einer Untersuchung der Relationalität zwischen Gefundenem, Erfundenem und Erlebtem förmlich zwingen.”) (Ette, ZusammenLebensWissen 32). 
Just like the Spanish conquerors, the Countess of Merlin sees Cuba's greatness and beauty as a gift from nature to the newly arrived Europeans. Nature to her is a literary kingdom, a source of exotic representations. And as for Cuba's cities, she sees them as places whose lack of history is made up for by exactly that impressive natural wonder on the island:

Our buildings have neither history nor tradition: the Havanan is entirely in the present and the future. His imagination is only struck and his soul is only moved by the sight of the nature that surrounds him; his castles are the gigantic clouds shot through by the setting sun; his triumphal arches are the vaulted sky; instead of obelisks, he has palm trees; instead of seigneurial weathervanes, the brilliant plumage of the guacamayo; and instead of a painting by Murillo or Raphael, he has the black eyes of a young girl, lit up by a moonbeam through the grating of the window. (Condesa de Merlín, La Havane II:210f.) $)^{36}$

The way that the Countess of Merlin uses possessive pronouns can be problematic; it is often difficult to clearly understand their referents. Who, for example, are "our poets"? Does she mean French, Spanish, or Cuban poets? The text does not make it clear, because she uses "our" (nos and notre) to mean all of those things: "our richest Parisian hotels” (I:74); “our European world” (II:49); “our elegant salons” (II:54); but also "our guajiros” (II:51; cf. Díaz 63). While her stubborn self-representation as a Cuban is obvious at first glance, however, there is also a fractured experience of identity that resonates at times (cf. Méndez Rodenas, "Journey" 709). Who am I? Now and here in the tropics? Countess or Creole woman? Santa Cruz y Montalvo or the Countess of Merlin? ${ }^{37}$ This ambivalence is closely connected to her political convictions: she sees herself not as a foreigner but rather as a colonizer, but one who understands her opinions as particularly legitimized by her rootedness in the island.

36 “Nos édifices n'ont pas d'histoire ni de tradition: le Havanais est tout au présent et à l'avenir. Son imagination n'est frappé, son âme n'est émue, que par la vue de la nature qui l'environne; ses châteaux sont les nuages gigantesques traversés par le soleil couchant; ses arcs de triomphe, la voûte du ciel; au lieu d'obélisques, il a ses palmiers; pour girouettes seigneuriales, le plumage éclatant du guacamayo; et en place d'un tableau de Murillo ou de Raphäl, il a les yeux noirs d'une jeune fille, éclairés par un rayon de la lune à travers la grille de sa fenêtre.” Cf. Díaz 65. 37 This turmoil also finds a clear expression in her memoirs, published in 1836: "There are two 'I's within myself that constantly struggle with each other, but I always encourage the 'strong' one, not because it is 'stronger' but because it is the more wretched, the one that achieves nothing." (“Existen en mi dos 'yo' que luchan constantemente, pero estimulo siempre al 'fuerte,' no por ser el 'más fuerte' sino por que es el más desgraciado, el que nada consigue.”) (Souvenirs et mémoires de Madame la Comtesse Merlin, publiés par elle-même, Paris, 1836, p. 246, quoted in Méndez Rodenas, "Voyage” 80). 
She consistently rejects the kind of national projects that one finds in Heredia or Villaverde. And with respect to political independence, her loyalty to Spain is unambiguous: "As for us, I repeat, we are deeply, exclusively Spaniards. ... Spain's interest is our own; our prosperity would be in service to the prosperity of Spain” (Condesa de Merlín, La Havane II:285). ${ }^{38}$ Her views on the contemporary debates over the abolition of slavery are equally radical. In her eyes, the enslavement of the blacks in fact represents civilizational progress for Africa, since it has led to a mitigation of the earlier barbaric customs that prevailed there with respect to the treatment of prisoners: "When a tribe took prisoners from an enemy tribe, if they were cannibals, they ate these captives; if they were not, they sacrificed them to their gods. The advent of the [slave] treaty introduced a change in this horrible custom: the captives were sold" (II:89). ${ }^{39}$

Given her radically conservative attitude, in a political climate that was set by such liberal debates as those that took place in the del Monte circle, it is no wonder that the Countess of Merlin met with quite a lot of contemporary criticism. This criticism was not, however, leveled only at her extremely conservative positions. Significantly, the main criticism against her had to do with her claim to be speaking as a Cuban, a claim that local writers considered to be completely without foundation. Félix Tanco wrote a number of articles in the Diario de la Habana in which he mocked her writing about Cuba from a European perspective: "The señora de Merlin, I will say it once and for all, saw the island of Cuba through Parisian eyes and could not understand that Havana is not Paris" (Méndez Rodenas, “Journey” 711)..$^{40}$

Taken as a whole, the Countess of Merlin's work conveys the sense of an extraterritoriality, to use George Steiner's terminology. La Havane is an important example of "unhousedness," which is so characteristic of Cuban literature. The text is a hybrid construction built on a series of paired opposites: Cuba vs. France; Spanish vs. French; localist costumbrismo vs. European exoticism; memory vs. present. She writes in an in-between, an intermediate space. Given her interest in cementing Spanish colonialism, her strained efforts to stage Cuban identity can only result in a fractured self-understanding as it relates to

38 "Quant à nous, je le répète, nous sommes profondément, exclusivement Espagnols. ... L'intérêt de l'Espagne est le nôtre; notre prospérité servirait la prospérité espagnole.”

39 "Lorsqu'une tribu faisait des prisonniers sur une tribu ennemie, si elle était anthropophage, elle mangeait ces captifs; si elle ne l'était pas, elle les immolait à ses dieux. La naissance de la traite détermina un changement dans cette horrible coutume: les captifs furent vendus." Cf. also Díaz 68, and the Countess of Merlin's article on the topic: Condesa de Merlín, "Les esclaves." 40 "La señora de Merlín, por decirlo una vez, ha visto la isla de Cuba con ojos parisienses y no ha querido comprender que La Habana no es París." 
identity. The experience of French colonialism and its more effective gravitational power is apparently what has led her to this colonizing behavior, but in her case it is not in the service of Paris but rather in the sense of the mother homeland Spain, Madre Patria España. However, she did not disappoint in service to France, as La Havane, which was intended for a French audience, would certainly have fulfilled that audience's exotic expectations. A model example of transcolonial knowledge transfer.

\section{III.3 Haiti As an In-Between Culture}

\section{III.3.1 The Haitian Turn}

With her 2004 book Modernity Disavowed, Sibylle Fischer, drawing on Michel Trouillot, introduced a new paradigm to research on the Caribbean. Fischer notes that Western philosophy fails to mention the Haitian Revolution, even though it was the only revolution whose central issue was racial equality. ${ }^{41}$

The colonial slave trade led to the development of a heterogeneous, transnational cultural network across an entire hemisphere. Fischer describes this cultural network as an "interstitial culture" (1): an intermediate culture, a landscape made up of heterogeneous facts, practices, and ideas that are broken up by disciplinary boundaries to this day. Haiti and the Haitian Revolution represent a central coordinate in this landscape, because there was a confluence of political imaginations and struggles for emancipation that developed precisely around the riddle of the Haitian Revolution-although it is often only graspable as the unspeakable, as a trauma, utopia, or fleeting dream (Fischer 2). ${ }^{42}$ What is crucial in Fischer's approach is that according to her, the true battles were fought in imaginary settings: "Imaginary scenarios became the real battleground" (2). ${ }^{43}$

41 I am grateful to Johanna Abel and Leonie Meyer-Krentler for comments on Sibylle Fischer and Chris Bongie.

42 An instructive example of looking at Haiti as an in-between culture can be found in Bandau, who uses an impressive textual example of the testimony of a white refugee about the events of the Haitian Revolution to examine the transcultural circulation of knowledge about Haiti in the area surrounding the Caribbean and the hemispheric space between Saint-Domingue, New Orleans, France, and New York. She addresses the media's negotiation and representation of the revolutionary events of 1791 to 1804 and asks to what extent the genre of the eyewitness report ensures the translatability of the events or, rather, regulates how they are represented. Cf. Abel, "Tagungsbericht" 476. On the Haitian Revolution see also, notably, James.

43 For interesting firsthand accounts written by white colonists trying to come to grips with a world that had suddenly disintegrated, see Popkin. 
The radical anti-slavery movement left a deep imprint on the psyche of the society that was built on the slave trade and the plantations: fantasies, paranoia, desires for identification, and denial were always a part of this formation (ibid.). Fischer strives to construct a landscape that lays bare the unspoken, the hidden, and the silenced in the historical evidence.

In the Caribbean, it was Cuba and Santo Domingo that were most directly affected by the events in Haiti: over time, Cuba took the place of the former Saint-Domingue as the Caribbean's major producer of sugar. Cuba's particular territorial position naturally meant that Haiti was at the same time far enough away and dangerously close (cf. Fischer 3). Significantly, from 1791 to 1805 there was not one single mention of the Haitian Revolution in Havana's Papel periódico (ibid.). This politics of silence also entailed the fact that in contemporary reports such as letters or articles, the revolution never came up as a political or diplomatic matter. ${ }^{44}$

In order to understand this phenomenon and to conceptually define the underestimation of Haiti's role in official historiography, Fischer suggests the concept of the disavowal, or denial, of modernity, both in the conventional sense (as a refusal of recognition) and the psychoanalytic sense (the repression of a traumatic experience). The disavowal thesis, somewhat like Paul Gilroy's "counterculture," has more to do with an attitude toward, or a perspective on, the past than with the supposed character of a particular historical moment. The concept of disavowal only works when we know that there is something that is being disavowed. It is a matter of identifying that which is forsworn and asking who is suppressing or disavowing it and why (cf. $37 \mathrm{f}$.).

Unlike the notion of trauma, which becomes politically inert when it cannot properly distinguish between, for instance, a traumatized slave and a traumatized slaveholder, disa-

\footnotetext{
44 Important encyclopedia articles are missing entries on colonialism and slavery to this day. In political theory, too, the case of Haiti is problematic. In her history of revolution, Hannah Arendt (On Revolution, 1936) leaves Haiti out. She excludes slavery from the social question. In Arendt, slavery cannot be discussed, because it does not fit in anywhere in her framework of the social versus the political. Slavery disappears in invisibility: literally, because institutions conceal it, and conceptually, in the abyss between the social and the political. Haiti becomes unthinkable. The same is also true from the perspective of economics: Adam Smith, Karl Marx, and Max Weber categorize slavery as pre-capitalist and therefore excluded from the discussion, even though the plantation economy was the economic foundation of European industrialization and only works in a capitalist global market. The conclusion of this intellectual history is that colonialism and slavery are only "noise," disturbances on the margins of history, anomalies, more or less disturbing irregularities in the triumphal march of progress and the development of individual liberties. Cf. Fischer $8 \mathrm{ff}$.
} 
vowal does not foreclose the political by rushing to assign victim status to all who find it difficult to deal with reality. (Fischer 38)

Chris Bongie, on the other hand, has noticed a scholarly shift since 2008 towards the Haitian Revolution, a shift that he calls the "Haitian turn" (Friends and Enemies). He highlights a political shift in the entire field of postcolonial studies, dating from September 11, 2001 and resulting in the inflationary interpretation of Caribbean cultural production as political and revolutionary. According to Bongie, this perspective is part of a prejudice on the part of the entire discipline, based on a confusion between the cultural and the political. Bongie's rebuttal uses Peter Hallward's designation of the culturalist approach as a nonsensical "disastrous confusion of spheres" (Hallward XIX, cf. Bongie, Friends and Enemies 263) that starts from the assumption that culture must always translate directly into progressive politics. The essence of Bongie's book Friends and Enemies is a critique of cultural politics and therefore, also, implicitly of Fischer, because she assigns a high level of political influence to culture.

The political shift in postcolonial studies involves a movement away from the enthusiasm of the nineteen-nineties for hybridity and (back) towards political engagement: Bongie designates this pole as "properly or substantively political" (328), unlike the popular culturalist studies of postcolonialism. It involves a departure from the consensus-oriented post-political ethos that marked postcolonial studies at the end of the twentieth century and a turn towards the willingness to establish boundaries that is a basic precondition for politics in the first place, just as the hostility of the Haitians towards the French was a precondition for their revolutionary victory. This brings us back to the divisive logic of the political, which Peter Hallward calls "divisive universality" and Chantal Mouffe defines as follows: "there is no consensus without exclusion, no 'we' without a 'they' and no politics is possible without the drawing of a frontier" (73, quoted in Bongie, Friends and Enemies 15).

According to Bongie, this more militant form of postcolonial studies offers a desperately needed counterbalance to the unchanging culturalist excesses of the same old postcolonialism, but it also opens up the horizon of (exclusionary) violence and terror that allows the "skeptical humanist" in all of us to judge the Haitian Revolution. Bongie formulates the difficulty of this turn as follows: "It is not easy to encompass the fractionalist logic of the political-the violent exclusion with which the distinctions between friends and enemies reveal them- 
selves-in a critical environment like ours in which the imperatives of an integrationist pluralism seem like common sense" (Bongie, "Politique" 234). ${ }^{45}$

In a strong, five-page-long critique of his favorite enemy, Nick Nesbitt, and his most recent book, Universal Emancipation: The Haitian Revolution and Radical Enlightenment (2008), which jumps onto the bandwagon of mainstreaming Haiti, Bongie stresses that Nesbitt leaves the afterpains of the Haitian Revolution out of his observations because the chronology of the events would disprove the thesis that the Haitian Revolution was a globally significant event ("Politique" 242-246). Current research on Haiti, Bongie continues, ignores the existence of two rival Haitis, drawing a careful line between the "good memory" (of the successful anti-colonial struggle and the "1804 idea" of radical racial equality) and the "bad memory" (of the racially divided nation(s) of Haiti in 1804 to 1820, the years immediately following the revolution): Alexandre Pétion's southern Republic, led by mulattos, and the "black" kingdom of Henri Christophe in the north replicate, says Bongie, the binary division into "friends and enemies" that is inherent in all politics. The fact that the world-historical triumph of the Haitian Revolution became bogged down in racism and absolutism and was, therefore, ultimately a failure is consistently ignored in the Haitian turn of postcolonial studies (241).

\section{III.3.2 Haiti Reception in the Caribbean Literatures}

How, then, are literary representations articulated with respect to Haiti? The fear of Saint-Domingue is a frequent theme in Caribbean literatures, especially in the first half of the nineteenth century. ${ }^{46}$ Maynard de Queilhe, for instance, talks about how slaves must be handled with severity and justice in order to avoid a second Saint-Domingue-this is the attitude of the slave-owning protagonists of the novel Outre-mer, where the concept of justice is interpreted as that which conforms to colonial jurisprudence, in other words with the right of the slave owner to act as he sees fit. ${ }^{47}$ The free blacks and mulattos are portrayed as opportunistic egotists, who want to create Haiti-like conditions on Guadeloupe and Martinique for the sake of their own private appetites (Wogatzke

45 'Il n'est pas facile, en un mot, d'englober la logique fractionniste du politique-l'exclusion violente avec laquelle les distinctions entre amis et ennemis se révèlent-dans un milieu critique comme le nôtre où les impératifs d'un pluralisme intégrationniste relèvent du sens commun." 46 On this topic see for example Johnson's historical study, The Fear of French Negroes: Transcolonial Collaboration in the Revolutionary Americas.

47 For more detailed information see Wogatzke 505. 
506). "Martinique, December 29, 1830, will become a second Saint-Domingue, a France of the Antilles! I am all for being named a deputy immediately afterwards" (Maynard de Queilhe II:182, cited in Wogatzke 506), ${ }^{48}$ one of the ringleaders declares, while another one is stirring up the masses with an encouragement to take whatever the whites do not freely offer: "But they offer nothing, so let us take everything. Saint-Domingue should attract and keep your eyes and your spirits. Saint-Domingue is the star of everything that we are going to do" (Maynard de Queilhe II:160, cited in Wogatzke 506). ${ }^{49}$ In the novel, it is only thanks to the stupidity of the slaves and the farsightedness of the masters that a second SaintDomingue can successfully be prevented (cf. Wogatzke 507). ${ }^{50}$

In Levilloux's Les créoles there is barely any mention of Haiti. This is all the more surprising given that the novel is set during the time of the Haitian revolts and that slave unrests in Martinique and Guadeloupe constitute a central theme of the novel. The erasure of Haiti is particularly noticeable because the novel, which covers the peak period of the revolution, the seventeen-nineties, is looking back from the retrospective viewpoint of forty-five years later at a time when all of the discussions on the French mainland about the recognition of Haiti (which became final in 1825) had already taken place. In the following, I summarize the few places where Haiti is in fact mentioned. One particular episode is Thélesfore's first report on the Haitian events, which are characterized as directly linked to the French Revolution:

\footnotetext{
“Great news, gentlemen,” exclaims Thélesfore as he enters, "news from Saint-Domingue!”

"From Saint-Domingue? What is it? What is it?" These exclamations arise from every corner of the apartment.

Thélesfore, with the importance felt by anyone in possession of an interesting secret, begins by stretching out in an armchair after having tossed his hat and his gold-handled cane to his young slave.

"Come on, what is it? The news!" they shout at him all at the same time, with redoubled curiosity and anxiety.

"It is nothing less than the infernal trail of powder whose head is in Paris and the tail here; it it starting to catch fire."
}

48 "La Martinique, le 29 décembre 1830, sera devenue une seconde Saint-Domingue, une France des Antilles! Je suis pour qu'on me nomme député immédiatement après.”

49 "Mais, ils ne donnent rien, prenons tout. Saint-Domingue doit attirer et fixer vos yeux et vos esprits. Saint-Domingue est l'étoile de tout ce que nous allons faire."

50 Walsh provides interesting insights into the very different decolonization of the French Caribbean. 
"What!" says Desvallon, "the principles that are being forged in the clubs have been pushed by the revolutionary hurricane as far as the great colony?" (Levilloux 70$)^{51}$

The debates taking place in the clubs of Paris seem to have found a resonance even in the great colony, the pearl of the French colonial empire. In the novel, what is revealing is Estève's immediate reaction: he pricks up his ears as soon as he learns that Vincent Ogé, in other words a mulatto, was the mastermind of the events in Haiti. And it goes on:

“That's exactly it," Thélesfore continues, "they send word from Port-au-Prince of the conspiracy by the mulatto Vincent Ogé, recently arrived from France.”

“Conspiracy!” several of the assistants repeat, in terror.

"Vincent Ogé, mulatto!” Estève says in a muffled murmur. $(70)^{52}$

The plantation owners react very negatively to the fact that the revolt originated with a mulatto. In answer to a question about the motivation of the rebels, "'Ogé was demanding civic and political equality in the name of who knows what madness,' Thélesfore responds, affecting a disdainful air" (71). ${ }^{53}$

Significantly, in Levilloux, it appears that the revolutionary events in Haiti must have been transmitted by way of French literature. It is therefore no accident that Levilloux uses Adonis as an important liberator, thereby borrowing from the first story by a French writer colleague about the Haitian Revolution,

51 - “De grandes nouvelles, messieurs, s'écria Thélesfore en entrant, des nouvelles de SaintDomingue!

-Saint Domingue! Quelles sont-elles? Quelles sont-elles!” Ces exclamations partent de tous les coins de l'appartement.

Thélesfore, avec l'importance de tout possesseur d'un secret intéressant, commence par s'étendre dans un fauteuil après avoir jeté son chapeau et sa canne à pomme d'or à son jeune esclave. "Enfin, qu'y a t-il? Les nouvelles! Lui crie-t-on à la fois avec un redoublement de curiosité et d'anxiété.

-Il ne s'agit de rien moins que de l'infernal traînée de poudre dont la tête est à Paris et la queue ici; elle commence à prendre feu.

-Quoi! dit Desvallon, les principes qui se forgent dans les clubs sont été poussés par l'ouragan révolutionnaire jusque dans la grande colonie?”

52 -C'est cela, continue Thélesfore, on nous apprend du Port-au-Prince la conjuration du mulâtre Vincent Ogé, récemment arrivé de France.

-Conjuration! Répètent avec effroi plusieurs des assistants.

-Vincent Ogé, mulâtre! Murmure sourdement Estève.

53 “'Ogé réclamait l'égalité civile et politique au nom de je ne sais quelle folie,' répond Thélesfore en affectant un air dédaigneux.” 
which shares the name: Picquenard's Adonis ou le bon nègre (Adonis or the good negro).

But how is the relationship to the Haitian Revolution articulated in Haiti's own literary production? A look at Émeric Bergeaud's novel Stella, published in 1859, shows that while the revolution is present there, its legitimacy derives only from the legacy of France, the former mother country. Stella gives the impression that from a constitutional point of view, all that the Haitians did was to assert the ideas of the rightful French government of Haiti, namely revolutionary France, against the will of the evil white Creoles (cf. Wogatzke 508). In Haiti it was the blacks and the mulattos who, together, rescued the high ideals of the French Revolution, which were diametrically opposed to the base interests of the plantation owners. Revolutionary France and freedom appear in the form of Stella, who at first participates actively in the struggle for human rights for all of Haiti's population groups, but then retreats into the mountains and leaves it to the brothers Romulus and Remus to carry out the fight for freedom (cf. ibid.; Bergeaud, Stella 91-97; Bergeaud trans. Hossman 83-89).

It is a credit to Haiti's mulattos and blacks that, in the end, they won their own freedom. Nevertheless, Stella, or also revolutionary France, is seen as the "initiator of the revolt," as an "adviser and moral support." Because of their "inexperience" the Haitians were dependent on the help of those who were more politically and strategically adept (Wogatzke 509).

Bergeaud honors the African roots of the Haitians, but the relationship to Africa is different in the work of his fellow Haitian writer Ignace Nau. In Isalina ou une scène creole (Isalina or a Creole scene) (1836), ${ }^{54}$ Nau describes the physiognomy of Galba, a friend of the protagonist's, Paul, as follows: "His broad, hairy head in no way resembles the true African type, which is considerably improved in our country" (Nau 46). ${ }^{55}$ Also notable in Isalina is the representation of the plantation economy, which is reminiscent of the idyllic picture painted in Maynard de Queilhe's Outre-mer. The story is set among the plantation workers, using the atmosphere of daily life and its sounds: the noise of the sugar mill, the comings and goings of the workers, and their singing convey a very particular mood. "Indeed, is there anything more lively, anything more varied and more picturesque than the sugar cane harvest?" (27). ${ }^{56}$ This critical attitude towards Africa, along with the endorsement of the plantation system, which in Haiti

54 I am grateful to Leonie Meyer-Krentler for comments on Isalina.

55 "Sa tête large et velue ne ressemble nullement au vrai type africain qui s'améliore considérablement dans notre pays."

56 "En effet, est-il rien de plus animé, rien de plus varié et de plus pittoresque que la roulaison!” 
right after the revolution are reconciled with Francophile tendencies, is at the same time juxtaposed with the positive presentation of the voodoo cult. Thus, Galba has a viper that he talks to so that it will not attack travelers. Paul brings him a problem, and he asks him to describe it. Paul asks him three questions: whether it was her injury that threw Isalina into a delirium; who it was that gave her the injury; and, if she has indeed been put under a spell, who it was that cast the spell over her. Galba asks what name she names in her delirium. In the following voodoo ceremony, Paul has the opportunity to see the answers to his questions on two cards as well as in a water jug, and he is given an antidote to the spell. Isalina is saved. In his gratitude, Paul offers to make Galba his adoptive son.

This ambivalence, in which relationships are explicitly affirmed that would be mutually contradictory in Western logic, corresponds to the specific dialectical situation that was discussed in the first chapter in the context of nineteenthcentury Haitian literary production (see I.3.5).

\section{III.4 Transfers of Ideas between the Center and the Colony}

\section{III.4.1 Philanthropy in the Center: Failed Transfers of Ideas}

The white Béké writers of Guadeloupe and Martinique never tried to claim anything other than French identity (Wogatzke 56). As the contemporary witness cited in the introduction to the French-speaking Caribbean commented, there was a downright brain drain towards Paris (Granier de Cassagnac I:102 f.; Wogatzke 56). The Békés acted as though culture were equivalent to French culture, which was reserved to the metropolis of Paris, while Creole culture was identified with the growing of sugar (Wogatzke 56). The only place where cultivated Frenchmen from overseas could find an atmosphere that suited them was in the metropolis:

The Creole world barely focused on intellectual and artistic work and disinterestedness. The only culture that was important to it was the cultivation of sugar cane. The few writers of Caribbean descent who stand out ... in literature will stay in the metropolis, where they will almost entirely forget the country of their birth. (Corzani II:24) ${ }^{57}$

57 "L'univers créole ne privilégiait guère le travail et le désintéressement intellectuel et artistique. La seule culture qui lui importait était celle de la canne à sucre. Les rares écrivains d'origine antillaise à s'illustrer ... en littérature resteront en métropole où ils oublieront à peu près totalement leur pays natal." 
The result of this division, into a cultural center located in France and an economic center located on the islands, was that the written culture of the French Antilles consisted mostly of historical and economic texts, which among other things pointed out the lack of their own historiographic or literary tradition and bemoaned the metropolis's lack of interest, but also criticized the apathy of a population that, in its own country, behaved as though it were only passing through.

The difficulty of transferring ideas from the metropolis to the colony is one of the central themes of the nineteenth-century French-speaking Caribbean. In Levilloux, the Creole Edmond Briolan is seized by the revolutionary atmosphere and develops philanthropical ideas there that cannot be implemented in the colonies.

There, his vigorous memory retraced his earliest impressions for him, too vivid to be erased from a sensitive soul. He felt how incompatible his philosophical convictions were with the social realities in whose midst he was destined to live. Born Creole, a member of a privileged caste whose power could only be maintained by the prestige of its superiority, he had been nourished on the most independent doctrines and dreamed enthusiastically of their political application. $(21)^{58}$

In a letter, Edmond's father warns his son against trying to transfer the ideas that the French Revolution might have inspired in him in Paris: equality cannot exist in the colonies (23). In a conversation between Edmond's mother and his sister, Lea, they are preparing for Edmond's arrival. Lea assumes that he will have been successfully assimilated in the capital and that he therefore belongs to the Parisian establishment. She tries to imagine the kinds of circles that her brother would have been a part of in Paris, at which point her mother corrects her.

\footnotetext{
"Mother, he must have gone to court, because a young Creole is never out of place anywhere. We who are in the highest position here cannot in France descend from our rank." "Court! My daughter, are you forgetting the scorn and the anger that the court inspires in Edmond? His letters are only full of the new principles that are tormenting all the minds in France. I tremble at the thought of how his feelings and his enthusiastic character will be threatened by severe trials in this country." $(38)^{59}$
}

58 "Là, sa vigoureuse mémoire lui retraçait ses premiers impressions trop vivaces pour s'effacer d'une âme sensible. Il sentait l'incompatibilité de ses convictions philosophiques avec les réalités sociales au sein desquelles il était destiné à vivre. Né créole, membre d'une caste privilégiée dont le prestige de supériorité pouvait seul entretenir la domination, il s'était nourri des doctrines les plus indépendantes et rêvait avec enthousiasme leur application politique.”

59 “'Maman, il a dû aller à la cour, car un jeune créole n’est déplacé nulle part. Nous qui sommes les premiers ici, nous ne pouvons pas en France descendre de notre rang.' 
Upon his arrival, Briolan thanks the slaves for their work, to which he owes his opportunities for further education: "And you, my good slaves, whose work has nourished my youth, has paid for my education, has woken me to the life of the mind; for you I will continue my mother's care and my father's gentleness. Come to my bosom; it is vast enough to hold all of you" (48). ${ }^{60}$

The non-transferability of antiracist ideas is an omnipresent problem. In Paris, unlike in the colony, skin color makes hardly any difference: "There he is, that pure-bred Creole, the living incarnation of a hateful privilege who would walk as my equal in France and here simply kicks me away within the unassailable circle of prejudices" (63). ${ }^{61}$ In the metropolis, racism is lifted for the benefit of praise for France: we see "good people of all colors of skin uniting for the triumph of France" (251). ${ }^{62}$

\section{III.4.2 Successful Transfers of Ideas}

In the Spanish Caribbean, the gaze is consistently directed towards Europe, often in order to copy the fashions found there. In Gómez de Avellaneda's Sab we see this most clearly in the citations that preface each chapter, drawn from French and Spanish Romantic literary models, making the orientation towards Europe explicit. Other important transfers play out primarily on an economic level: such things as the gambler's morality of the English, in the person of Otway, and the function of the lottery play a prominent role.

In Manzano's Autobiografia ${ }^{63}$ the French proponents of the Enlightenment are present as Anti-Christs: Manzano's mistress sees his future as being

'La cour! ma fille. Tu oublies donc le mépris et les accens de colère qu'elle inspire à Edmond? Ses lettres ne sont pleines que des principes nouveaux qui, en France, tourmentent tous les esprits. Je tremble que ses sentimens et son caractère enthousiaste ne soient menacés de bien rudes épreuves dans ce pays."”

60 "Et vous, mes bons esclaves, dont le travail a nourri ma jeunesse, a payé mon éducation, m’a fait naître à la vie de l'intelligence; pour vous je continuerai le soins de ma mère, la douceur de mon père. Venez dans mon sein, il est assez vaste pour vous contenir tous."

61 "Le voilà donc ce créole de pure race, l'incarnation vivante d'un odieux privilège qui, en France, marcherait mon égal, et ici me repousse du pied dans le cercle infranchissable des préjugés."

62 "les braves de toutes les peaux s'unir pour le triomphe de la France."

63 Juan Francisco Manzano (Cuba, 1797-1853) was a slave and a novelist. Most of his works were written when he was still a slave; he probably wrote his autobiography in 1835, encouraged by Domingo del Monte, on whose initiative a group of liberal intellectuals bought Manzano's freedom in 1837. Cf. Bremer ("Juan Francisco Manzano"), who explores the reception history 
"worse than that of Rousseau and Voltaire," which she takes as a justification for her rigorous suppression of his intellectual talents. There are also connections to French opera; to the landowners of the Iberian Peninsula (Galicia); to the English drawing instructor, Mr. Godfria; but there are trans-Caribbean connections as well, to emigration from Santo Domingo. In spite of the critical portrayal of the treatment of slaves, the picture that has already been drawn, in the context of Haiti, of a dialectical relationship to the master appears as well. When Manzano was sixteen years old, for instance, he was so fascinated by the newly produced gold coin bearing the likeness of the Spanish king Ferdinand VII that he kept it and cherished it. ${ }^{64}$

The issue of transfer processes in the Spanish Caribbean is more complicated in Galván's ${ }^{65}$ Enriquillo than in Gómez de Avellaneda or Manzano; in Galván, "colonial transfers of beauty” (Abel, “Aunque la virgen””) are staged between Italy, Spain, and the Americas. Galván often talks about the manner of dressing according to Milanese fashion (Galván, Enriquillo, Notas 135): a case of reverse exoticism. Another transfer theme can be found in the communication difficulties that arise from misunderstandings and hurdles on the information paths, namely the slow-grinding mills of transatlantic bureaucracy (372). Transfers of egalitarian ideas, on the other hand, occur much more frequently in a trans-Caribbean dimension. Thus, for instance, the trans-Caribbean resistance of the Taínos constitutes a central axis in Enriquillo: Hatuey (from Haiti) flees to Cuba and organizes the fight against the conquest of Cuba by spying between the islands (294f.) The multirelational orientation of the Spanish Caribbean also functions on a subversive level: pirates use the colonial masters to transport Indian slaves

of this, the only known autobiography of a former slave in the Spanish Caribbean, examining the transfer processes of its reception between Cuba, Spain, England, France, Ireland, and Haiti. A central question for Bremer is to what extent Cuban literature was given an initial push by British abolitionists like Richard Madden, who, working as eyewitnesses and agitators against slavery, politicized the literary discourses of the Caribbean islands. After reports by English travelers had considerably sharpened the tone of the discussions between the Spanish and English crowns about the abolition of slavery, there followed a further internationalization of the reception of Manzano's autobiography when the abolitionist Victor Schoelcher translated it into French in 1840.

64 I am grateful to Johanna Abel for comments on Manzano, Enriquillo, and Tapia y Rivera. 65 Manuel de Jesús Galván (1834-1910), a diplomat and political functionary, had a classical humanist academic education. His life is closely intertwined with the history of the Dominican Republic's independence: he was first a staunch annexationist (in 1861), only to become a supporter, in his thirties, of the Partido Azul under Luperón (starting in 1868). As a diplomat, he was active in France, among other places. It was in Paris, in the Bibliothèque nationale, that he conceived his single novel, Enriquillo (first published in 1879, and first complete edition in 1892). 
among the Caribbean islands (410). On a fundamental level, the novel exhibits a deep understanding of the zeitgeist of the Spanish conquests. Galván paints a haunting portrait of Castilian court culture and of the conquistadors' sense of mission. There is a pervasive latent sympathy for the world power that is Spain, with the great minds of Columbus and Las Casas. This does not exclude the possibility, however, unlike in the literary examples from the French Caribbean, that Enriquillo could rebel in anticipation of the struggles for liberation and wars of independence with the Spanish colonial power: "The uprising of the Bahoruco is seen as a reaction; as the prelude to all the reactions that will annihilate the right of conquest in the New World within less than four centuries" (Galván, Enriquillo, Notas 534). ${ }^{66}$ In a critique of the times by Galván there is a reference to Spain's political decadence:

The Royal Council of the Indies, against the perverse hopes of King Ferdinand and inspired by the dignity and independence which so ennobled Spanish institutions in that century, unanimously decided in favor of the rights demanded by Don Diego, reinstating Columbus's achievement in all its pure brilliance. In spite of this glorious triumph of justice over power ... (115; emphasis mine $)^{67}$

In Tapia y Rivera's La palma del cacique (The chieftain's palm tree), ${ }^{68}$ the relationship to contemporary Castilian literature constitutes an important axis; this can be seen, for example, in an intertextual reference to Cervantes and the imaginary folly of the chivalric novel: the protagonist, Sotomayor, wants to accomplish heroic deeds in the New World before his wedding.

These ideas, on the other hand, were very natural and proper among the distinguished youth of his time, because the chivalric structure that Henry I of Germany had established was still in place, and the greatest and most exceptional of satirists had not yet torn it down with his implacable pen. Once the Iberian Peninsula was free of Muslim dominion, with the capture of the Granadan stronghold, the adventurous and militant spirit of the Spaniards discovered a new and larger terrain in which to express itself than what Flanders and

66 "El alzamiento del Bahoruco aparece como reacción; como el preludio de todas las reacciones que en menos de cuatro siglos han de aniquilar en el Nuevo Mundo el derecho de conquista."

67 "El Consejo Real de Indias, contra las protervas esperanzas del Rey Fernando, inspirándose en la dignidad e independencia que tanto enaltecieron en aquel siglo las instituciones españolas, falló unánimemente en favor de los derechos reclamados por Don Diego, reintegrando en todo su puro brillo el mérito de Colón. Sin embargo de este glorioso triunfo del derecho sobre el poder ...”

68 Alejandro Tapia y Rivera (Puerto Rico, 1826-1882) was a prolific writer and essayist, working in many genres, who is considered the "father of Puerto Rican literature." He was also active in the causes of abolition and women's rights. 
Italy could offer; thus, it was not surprising that ardent youth should swarm to the newly discovered lands where a thousand fanciful ventures took place in the novelistic imaginations, with the reporting of strange adventures, great exploits, and golden regions, where marvels mixed with the vastness and the unknown of those countries. (47; emphasis mine $)^{69}$

In Tapia y Rivera, under European influences, there is a preponderance of exoticized images of the foreign woman: the sultana and the heavenly Arabian beauty, but also the trans-cultured body of the exotic Andalusian woman and the Greek bodily ideal of the nymph. In addition to those we also find Herculean warriors (Tainos) and Castilian heroes (Cid-Salazar). Also important are imaginary transfers of the indigenous protagonists to Europe and the mirroring against their European counterparts, for example Guarionex as a knight: "Guarionex translated to Europe and educated to feudal customs would have been, obeying his passionate and valiant heart, a completely noble and accomplished cavalier" (40; emphasis mine).$^{70}$ The female characters experience the same kind of transfer, when Tapia y Rivera imagines Loarina as a European and reflects the "wild woman" in a "cultivated lady," who strategically manages her feelings: "A similar struggle in Loarina's heart was natural, who ... felt herself blush at the knowledge that her desire was driving her to love another; because the beautiful savage was not the cultured lady of our times" (42; emphasis mine). ${ }^{71}$

Transfers of philosophical ideas, then, especially in the French-speaking Caribbean, are represented as failed, whereas in the Spanish-speaking Caribbean they fall on fertile soil, as shown by the case of Heredia in the previous chapter. Literary and aesthetic models, often exoticized, are also shown as successful transfers there. And yet, although the reception in the two colonial spheres is

69 "Estas ideas, por otra parte, eran muy naturales y propias en la juventud distinguida de su época, pues aún estaba en pie el caballeresco edificio que levantó Enrique I de Alemania, y que aún no había derribado con su implacable pluma, el más grande y singular de los satíricos. Libre la península ibérica del dominio musulmán con la toma del baluarte granadino, el espíritu aventurero y belicoso de los españoles, encontraba un nuevo terreno más vasto a su ejercicio, que el que podía ofrecerles la Flandes y la Italia; así que no era de extrañar que la juventud ardorosa, acudiese en tropel a las tierras nuevamente halladas, en donde mil empresas quiméricas se hacían lugar en las imaginaciones novelescas, con la relación de extrañas aventuras, de grandes proezas, y de doradas regiones, en que los prodigios se mezclaban a lo vasto y desconocido de aquellos países."

70 "Guarionex trasladado a Europa y educado a usanza feudal, habría sido, obedeciendo a su corazón apasionado y valiente, todo un noble y cumplido caballero.”

71 "Natural era una lucha semejante en el corazón de Loarina, que ... sentía rubor al conocer que su veleidad la impulsaba a amar a otro; porque la hermosa salvaje no era la culta dama de nuestros tiempos." I thank Johanna Abel for this reference. 
so different, what remains true is that whether failed or successful, a one-to-one transfer is never possible, and any product from the center is staged as an amalgam in the Caribbean texts.

\section{III.5 The In-Between and the Figure of the Mulatto}

From the heights of their privilege, the whites shower contempt down onto the mulattos, men molded by their blood. These latter, humiliated by their inferiority, cast the hatred of envy towards their fathers and take revenge on the blacks for the degrading shade of skin to which they are heir. The Negroes, for their part, recognizing the superiority of the whites and rejecting the pretentions of the colored class, conspire against the first because they are the masters and despise the second because they aspire to become so. (Levilloux 14 ${ }^{72}$

A constant struggle around attributions of ethnic identity can be seen in Levilloux. There is no conversation that does not include a determination of skin color. The mulatto Estève insists that he and the white Creole Edmond are both Americans: "we are two American shrubs on the soil of Europe, far from our beautiful sky" (25). ${ }^{73}$ And yet, in spite of the strong definitional drive towards clear attributions, there nevertheless remains a kind of latent uncertainty. At one point, for instance, free and unfree mulattos are described as two different groups. Estève, as a mulatto himself, observes: "When he left, he was old enough, he had had reason enough to observe and remember the superiority that the free mulattos and mestizos assumed, especially in relation to the blacks" (27) ${ }^{74}$ From the point of view of the blacks, the mulattos are sometimes pitied, and recognized as being located in the in-between: thus, the herbal healer Iviane, for instance, has sympathy for Estève. And the concept of the nation, interestingly enough, has something to do with that: "Me possessed by God alone,' retorted the old woman. 'You mulatto, me Negress. Nation of mine is large in a large country. You not have a nation, you'” (104). ${ }^{75}$

72 "Du haut du privilège les blancs laissent tomber le mépris sur les mulâtres, hommes pétris de leur sang. Ceux-ci humiliés de leur infériorité, lancent à leurs pères la haine de l'envie et se vengent sur les noirs de la nuance dégradante d'épiderme dont ils sont héritiers. De leur côté les nègres reconnaissant la supériorité des blancs, repoussant les prétentions de la classe de couleur, conspirent contre les uns parce qu'ils sont maîtres, et haïssent les autres parce qu'ils aspirent à le devenir." On this aspect in Levilloux see also Meyer-Krentler, "El Bois-Caïman.”

73 "nous sommes deux arbustes américains sur le sol de l'Europe, loin de notre beau ciel." 74 "A son départ il était assez âgé, il avait assez de raison pour avoir observé et gardé souvenir de la supériorité que les mulâtres et les métis libres affaictaient sur les noirs surtout.”

75 “'Moi possédée de Dieu seul,' répliqua la vielle. 'Vous mulâtre, moi negresse. Nation à moi est grande dans un grand pays. Vous pas avoir une nation, vous.”” 
The only way to avoid the stigma of the word mulatto is to flee. "Then, let us go away, leave the Antilles, flee to France or to the American continent. Then there will be no more terrors, we will be free, free from the tyranny of a word, mulatto" (110). ${ }^{76}$ Estève feels torn in both directions. From Paris, he writes back to his father:

My father ... why did you separate me from my country? Why did I not grow upon the soil that witnessed my birth? Why this vain and fatal education which must cause my misery? It is in vain that my learning, my knowledge shall raise my ambition; the whites will reject me; my peers, wounded by my superiority, will envy me. It will be a light that is shut up inside me and which will only better illuminate the horror of my isolation. (28) ${ }^{77}$

Maynard de Queilhe depicts the mulattos very critically. They are usually the ones who break the rules of the Code Noir. After free men of color (hommes de couleur libres) had received political and civil rights in 1831, it is they who pose the greatest danger of sedition, in his opinion. They become increasingly disrespectful:

Most of the time, they were ridiculous or odious. As the price of their insolences, they were beaten with a cane. ... Protected by the night, they would cover the walls with vile placards, on which they did not blush to insult and threaten the most honorable existences in the country. ... They ceased to salute the wives and daughters of their masters or former masters. Their songs resounded with the word freedom, which has never been a good sign. (Maynard de Queilhe I:161) ${ }^{78}$

In Les amours de Zémédare et Carina, the mulatto Dérima is depicted as being on the side of slavery. This is not all that surprising, since a large proportion of the mulattos themselves owned slaves.

76 "Ensuite, partons, quittons les Antilles, fuyons en France ou sur le continent américain. Alors plus de terreurs, nous sommes libres, libres de la tyrannie d'un mot mulâtre.”

77 "Mon père ... pourquoi m’as-tu éloigné de mon pays? Pourquoi ne me suis-je pas développé sur le sol qui m'a vu naître? Pourquoi cette vaine et fatale éducation qui doit faire ma misère? C'est en vain que mon savoir, mes connaissances élèveront mon ambition; les blancs me repousseront; mes semblables, blessés de ma supériorité, m’envieront. Ce sera une lumière enfermée en moi et qui ne sait que mieux éclairer l'horreur de mon isolement."

78 "Ils étaient la plupart du temps ridicules ou odieux. Pour prix de leurs insolences, ils se faisaient rompre de coups de canne. ... A la faveur de la nuit, ils couvraient les murs de placards infâmes, où ils ne rougissaient pas d'insulter et de menacer les existences les plus honorables du pays. ... Ils ne saluaient plus les femmes et les filles de leurs maîtres ou de leurs anciens maîtres. Leurs chansons retentissaient du mot de liberté, ce qui n’a jamais été bon signe.” 
The free man of color would certainly be treated the worst if he dared to declare himself against the white men. The slaves, having shaken off the yoke of their masters, would be properly subjugated by the enormous forces that would be easily sent from Europe. ${ }^{79}$... After the victory, the free men of color, no longer able to be useful and having proven themselves dangerous, would all be massacred and that would be done, I say, with justice.Does anyone suppose, for that matter, that the slave, who does not want to be subject to white men, whose superiority he nevertheless recognizes, would prefer men of color, descended from Whites, envied and detested by the Negroes? (Prévost de Sansac $170 \mathrm{f}$. , cited in Corzani II:36) $)^{80}$

This mulatto speaks like a free man and, in the process, defends all of the values of the colonial society.

In contrast to these examples from the French-speaking Caribbean, mulattos in texts like Sab and Cecilia Valdés, from the Spanish-speaking Caribbean, are much more often presented as positive figures, possessing a cohesive, integrative force. The texts are marked by the way in which the concrete designation of color already conveys an in-between that has no clearly definable place in the social structure. What all the texts have in common is the uncertainty, or even impossibility, of positioning the mulatto.

\section{III.6 The Island Function, or between Nature and Culture}

"Altogether, there are times when I envy you, you a poet exiled in a sunny land, an exile which Ovid would have loved, in that beautiful Martinique which you have described so admirably" (Hugo, Letters 56). ${ }^{81}$ These words are from a letter written by Victor Hugo in 1835 to his writer colleague Louis de Maynard de Queilhe, who had set out shortly before from Paris for Martinique, his island of origin.

79 He is referring here to Leclerc's expedition to Saint-Domingue.

80 "L'homme de couleur libre serait certainement le plus maltraité, s'il osait se déclarer contre les hommes blancs. Les esclaves, ayant secoué le joug de leurs maîtres, seraient proprement subjugués par les forces immenses qu'on enverrait facilement d'Europe. ... Après la victoire, les hommes de couleur libres ne pouvant être utiles et s'étant rendus dangereux, seraient tous massacrés et ils le seraient, je le dis, avec justice.-Supposera-t-on d'ailleurs que l'esclave, qui ne veut pas être soumis à des hommes blancs, dont il reconnaît cependant la supériorité, lui préférait des hommes de couleur, sortis des Blancs, jalousés et haïs par les Nègres?”

81 "Il y a des heures où je vous envie, vous poète exilé sous le soleil, exil qu'Ovid eût aimé, dans cette Martinique que vous avez si admirablement peinte” (Hugo, Bug-Jargal 69). 
"But for me, to abandon my homeland. ... Why does there exist an island named Martinique? Why am I here instead of elsewhere?” (Maynard de Queilhe $\mathrm{I}: 43)^{82}$-this is the plaint of Marius, the hero of Maynard de Queilhe's Outre-mer, when he has to return from England to the island of his birth. The novel was written only a few years after the exchange of letters cited above. Here we see how various the values are that can apparently be easily projected onto the colonial Caribbean islands.

In the novel Eugène de Cerceil ou les Caraïbes (Eugène de Cerceil or the Caribbean) (1824), by J.H.J. Coussin (Guadeloupe 1773-1836), we find an island metaphor that is strongly oriented towards isolation and exile. It refers to the feeling of being banished into the distance, far from any civilization or cultural possibilities. The author writes about himself in the preface:

Living far from the literary world, on an island in the American archipelago and in the midst of the wild places that he was trying to describe, he could not resort to the advice of enlightened and straightforward friends who would perhaps have taught him to think even more negatively than he is already inclined to do of these ramblings of his spirit. (Coussin I:xxiii) $)^{83}$

It is significant that the island is located in an American archipelago. And Coussin adds in a footnote:

Although learning and literary knowledge are rather rare in the country where this work was composed, the author would be wanting in gratitude if he did not declare here that certain persons, to whom (long after having written this Preface) he had sent copies of his manuscript, had given him good advice from which he profited. (ibid.) $)^{84}$

Thérèse Bentzon's Yette. Histoire d'une jeune créole (Yette. The history of a young Creole woman) (1880) also shows, right from the beginning, that the thematic introduction to the plot can only work by passing through the most exotic island

82 "Mais, moi, abandonner ma patrie. ... Pourquoi existe-t-il une île appelée Martinique? pourquoi suis-je ici plutôt qu'autrepart?”

83 "Vivant loin du monde littéraire, dans une île de l'Archipel Américain, et au milieu des sites sauvages qu'il a essayé de décrire, il n'a pas eu la ressource de recourir aux conseils d'amis éclairés et francs qui lui auroient peut-être appris à penser encore plus désavantageusement qu'il n'est porté à le faire de ces élucubrations de son esprit."

84 "Quoique le savoir et les connoissances littéraires soient assez rares dans le pays où cet ouvrage a été composé, l'auteur manqueroit à la reconnaissance, s'il ne déclaroit ici que quelques personnes, auxquelles (long-temps après avoir écrit cette Préface) il a communiqué son manuscrit, lui ont donné de bons conseils dont il a profité.” 
depictions. ${ }^{85}$ The novel's "frictional" features are particularly evident (cf. Ette, "Eine Literatur ohne festen Wohnsitz"), but it also suggests a clear ethnographic reading, like some literary Caribbean texts:

\begin{abstract}
All travelers who have visited the Antilles and sailed along the steep coastline of one of our most beautiful colonies, Martinique, remember the picturesque look of the sugar plantations, between the double blue of the sky and the sea, the factory smokestacks, the farm buildings, and the Negroes' huts covered in straw, sheltered from the tropical sun by the disheveled foliage of the coconut palm trees. $(279)^{86}$
\end{abstract}

Unlike later understandings of the Caribbean, the nineteenth-century conceptions of the islands share the idea of exile and isolation. Any positive island imaginaries derive from the most exotic notions. And because the island is generally only "tolerated," as a way station, it is also a part of an in-between that is symptomatic of writing in and about the nineteenth-century Caribbean.

This imagery of isolation and exile in connection with islands can be found in the French Caribbean in particular. In Galván's Enriquillo, instead of an explicit confrontation with insularity, we find individual descriptions of landscapes as idyllic and perfectly planned by nature. The European traveler's descriptions of euphoria over nature are matched in Fray Bartolomé de las Casas's enthusiasm. They are inscribed in the established, quasi-religious, European tradition of that time of admiring nature as an aesthetic work of art. Las Casas is an intellectual traveler who ecstatically devours the exotic landscape.

Las Casas, endowed with an exquisite sensibility, a fervent admirer of the beautiful, felt his mind transported on wings of the purest and most religious enthusiasm, contemplating the rich variety of lacquers and hues with which provident Nature has decorated the fertile, rugged soil of Hispaniola. He paused, like a child, showing signs of amazement and joy, now at the majestic sight of the far-off mountain range, now at the view of the wide plains or at the feet of the erect mountain that reached its crest, bushy with pines and baitoas [an indigenous tree]. Everything was a motive for ecstasy for the impressionable traveler, who eloquently expressed his admiration, wanting to share it with his companions; they, however, not as rich in artistic sentiment, or maybe poor in imagination or lyricism, remained

85 Thérèse Bentzon (actually Marie Thérèse Blanc, France 1840 -1907) was a French journalist, novelist, and a longtime contributor to the Revue des deux mondes. She traveled through the Caribbean and, in addition to her novels, wrote articles about Caribbean literature and social conditions.

86 "Tous les voyageurs qui ont visité les Antilles et longé le littoral escarpé d'une de nos plus belles colonies, la Martinique, se rappellent l'aspect pittoresque des habitations sucrières dont on aperçoit, entre le double azur du ciel et de la mer, la cheminée d'usine, les bâtiments d'exploitations et les cases à nègres couvertes en paille qu'abrite contre le soleil tropical le feuillage échevelé des cocotiers." 
with stoic cold in front of the superb spectacles that electrified the graduate. (Galván, Enriquillo, notes $249 \mathrm{f}$. $)^{87}$

Thus, the nature that is present on the islands is made into a pars pro toto in the functionalization of the island as metaphor. This suggests both a dissociation from the center and a break with the colonially established bipolar axis.

In Juan Francisco Manzano's Autobiografia, nature, in the sense of the natural environment, is not depicted romantically. It only appears as a medicinal resource for lightening the depressive state of his soul, in the context of walks that are prescribed to him or when he is supposed to go hunting and fishing with his doctor on his masters' lands as a way of recuperating. But it is always domesticated culture that is his undoing, as in the case of the geranium. Culture appears in the context of drawing and writing, among other places. Manzano is given drawing lessons early on, along with the masters' children; he proves to be very talented, but then he is forbidden to continue after he draws a witch copulating with the devil. At that point his father throws his drawing materials into the river. His father plays the harp and is a part of the contemporary black musician culture, classical ensembles that play at the masters' baptisms and parties. His mother also acts as a vehicle of culture, having been chosen by her mistress to be educated in particularly civilized skills and having internalized courtly customs. Manzano, therefore, is the product of a cultured family home, and his parents made sure that he did not consort with the black slave children who did not belong to their household. But because access to "(written) culture" was, however, denied him (with bans on writing, drawing, and speaking), he transposes his abilities into orality, incessantly reciting poems, sayings, prayers, verses, and psalms and even entering into imagined dialogues with objects such as tables and chairs. Manzano speaks of the "notebook in his imagination" (cuaderno en la imaginación) where he kept his poems and could retrieve them when he needed them for improvisations. His verbal giftedness earns him

87 "Las Casas, dotado de sensibilidad exquisita, ferviente admirador de lo bello, sentía transportada su mente en alas del más puro y religioso entusiasmo, contemplando la rica variedad de esmaltes y matices con que la próvida Naturaleza ha decorado el fértil y accidentado suelo de La Española. Deteníase como un niño haciendo demostraciones de pasmo y alegría, ora al aspecto majestuoso de la lejana cordillera, ora a vista de la dilatada llanura, o al pie del erguido monte que llevaba hasta las nubes su tupio penacho de pinos y baitoas. .... Todo era motivo de éxtasis para el impresionable viajero, que expresaba elocuentemente su admiración, deseoso de compartirla con sus compañeros; los cuales, no tan ricos de sentimiento artístico, o más pobres de imaginación y lirismo, permanecían con estoica frialdad ante los soberbios espectáculos que electrizaban al Licenciado." 
the epithets of "speaker" (parlero) and "gift of the gab" (pico de oro, literally "golden beak").

In Alejandro Tapia y Rivera's La palma del cacique, the natural world of the islands functions as a mirror of the characters' mental state, illustrating their melancholia and despair. The "wild" culture of the chieftains corresponds to an "intelligence" of the rain forest: "the pleasant and enormous, though uncultivated, intelligence, like the eternally green forests" (54) ${ }^{88}$ Indigenous thinking is staged, in the novel, as literature, from the point of view of the Euro-Creoles. ${ }^{89}$

The opposition between nature and culture is treated as a much more clearly polarized division in the literature of the French Caribbean than in the Spanish texts. This corresponds to a different function that is served by islands in the two colonial spheres: the island imagery of exile and isolation that is frequently found in the French Antilles-from the mouth of the plantation-owning oligarchy that chose to settle there-is barely to be seen in the Spanish Caribbean.

\section{III.7 Between Trans-Tropical Dimensions: Xavier Eyma and the Philippines}

Xavier Eyma, a Martinican writer who mostly traveled between Saint-Pierre (on Martinique), Paris, and New Orleans and who was a proponent of slavery, was concerned with influencing the debates in New Orleans in such a way that the southern states of the United States did not also abolish slavery, as had already been done in the French colonial empire in 1848. His descriptions of transfers of ideas and experiences, descriptions that unfold over an immense body of narrative and essayistic work, move across multiple colonial axes over the area of the entire French, but also Spanish, colonial realm. In his essay La vie aux États Unis (Life in the United States), for instance, he compares cock fights in Cuba with cock fights in Mexico and in Manila (280). The line connecting Cuba, Mexico, and the Philippines is one that he simply takes for granted. "Cock fights are as popular in Cuba as they are in Mexico and Manila. They take place on Sunday afternoons in the villages in the interior of the island" (274). ${ }^{90}$ Eyma compares plantation owners in Cuba with plantation owners in Louisiana just as naturally:

$\mathbf{8 8}$ "la inteligencia, aunque inculta, amena y gigante, como las selvas siempre verdes."

89 I am grateful to Johanna Abel for comments on Manzano, and Tapia y Rivera.

90 "Les combats de coqs sont aussi populaires à Cuba qu'au Mexique et à Manille. C'est l'aprèsmidi du dimanche qu'ils se donnent dans les villages de l'intérieur de l'île.” 
I must say that the planters of the island of Cuba are without contest the noblest hearts in the world. The southern planters of the United States make up a charming population. Many of them are rich, all of them are hospitable, quite a few are intelligent, enlightened, and sensitive; but they do not surpass the Cuban planters in refinement, in intelligence, or in wealth. As for their fortune, it is doubtful whether one could find more affluent men anywhere in the world than the most affluent of the Cuban planters. $(267)^{91}$

What is striking is how open Eyma is towards the Spanish colonial regime, which he praises for being able to hold onto Cuba, the "ever-faithful" island ( $L a$ siempre fiel); in fact, he even seems to be holding up Spanish colonialism as a model for the French colonial empire (266). Eyma thinks within colonial systems, but he definitely compares their cultures with each other, including their political cultures. The French Creole upper class is interconnected, as he sees it, very tightly across the most varied regions of the world. Thus, for instance, he expresses himself very sympathetically towards the Louisiana Creoles, and also compares the French "Creole race" around the world with the Anglo-Saxons. Writing about New Orleans, almost a divided city, he remarks: "There is more than political antipathy today, there is an absence of social sympathy between the Creole race and the Anglo-Saxon race" (47). ${ }^{92}$ Eyma takes similar global conceptions of regional relationships as the basis for his novel Le roi des tropiques (The king of the tropics). He does not differentiate here among the various Caribbean islands, nor between the Caribbean and the area around it: he considers the tropics as one zone. Ette has pointed out that the tropics constitute at the same time a center and a transitional space, both the center of the globe and the threshold to another world that is familiar to Europeans: a shifting figure that is constantly being reformulated and both artistically and cartographically redrawn within the Western pictorial tradition.

While the examples of Levilloux and Maynard de Queilhe suggest that transfers take place on a one-dimensional, bipolar axis between the mother country and the colony, transfers take on a definitely multidimensional character in Eyma. He takes as his frame of reference not only the Caribbean periphery but goes far beyond that, including the Philippines as well. The fact that Manila

91 "Je dois dire que les planteurs de l'île de Cuba sont incontestablement les plus nobles cœurs du monde. Les planteurs du Sud, aux Etats-Unis, forment une population charmante. Beaucoup sont riches, tous sont hospitaliers, plusieurs sont intelligents, éclairés et délicats; mais ils ne surpassent point les planteurs cubains en raffinement, en intelligence et en richesse. Quant à la fortune, il est douteux qu'on puisse rencontrer au monde des hommes plus opulents que les plus opulents des planteurs cubains.”

92 "Il y a plus que de l'antipathie politique aujourd'hui, il y a absence de sympathie sociale entre la race créole et la race anglo-saxonne.” 
was subject to Spain's rule and influence for several centuries is due to its strategic position on the naval route between the American continent and Asia, especially China. The silver trade route, which was especially booming before the nineteenth century, meant that Spanish trade galleys kept arriving in the Philippines, bringing not only precious metals and luxury goods from Asia but also cultural goods. Thus, a close relationship developed between the Philippines and Mexico, which was also reflected in literary production and was a contributing factor to the close connection between Philippine typography and that of the Spanish viceroyalty. Many of those who began their literary career in the Philippines received the opportunity to present their intellectual work in Mexico. This included the Dominican Francisco Blancas de San José, the father of book printing in Manila; Dr. Don Antonio de Morga, the governor of the Philippines, judge of the royal high court of Mexico und president of the high court in San Francisco de Quito; Don Diego de Camacho y Ávila, first the archbishop of Manila and later the bishop of Guadalajara; and Diego de Gorozpe, born in Puebla, a monk and later the bishop of Nueva Segovia (in the Philippines) (Laslo 9).

Eyma's openness to the Philippines does not, however, mean that he therefore questions the colonial status quo. On the contrary, he affirms France as a colonial power everywhere that he can. France, very much in the spirit of the civilizing mission (mission civilisatrice), was successful in implementing the spread of its colonial and cultural influence, although Eyma does regret the abolition of slavery, seeing it as a grave mistake, and seems to want to turn back the wheels of time.

What we see happening on the literary level in Eyma is the focus of a current scientific paradigm in the more recent publications of Ottmar Ette, where he programmatically argues for a further conceptual opening of Caribbean research beyond the Atlantic and for the integration of the Pacific archipelago into the research on nineteenth-century hemispheric transfer processes. From the very beginning, the perception of the Caribbean islands involved a trans-archipelagic island fiction, given that Columbus, taking his cue from Marco Polo, invented America as Asia. It was not until the end of the nineteenth century that the Cuban José Martí and the Philippine José Rizal first destroyed the fiction of the colonial kaleidoscope, which had held sway since Marco Polo, and understood their archipelagoes as translocal worlds whose whirlwinds would eventually do away with the colonial systems. Ette describes the Caribbean archipelago as a fractal world that shares a "translocalized local diversity" with other archipelagic zones of tropical consumer goods. This approach should ultimately lead to a more radically dynamic understanding of the Caribbean in a global context and according to vectorial modals (cf. Ette, "Le monde transarchipélien”). 


\section{III.8 Between Literature and the Natural Sciences}

There was a great deal of interest in the natural world of the Caribbean islands in the nineteenth century, from two sides: on the one hand as a wild, romantic, and paradisiac setting for literary works, and on the other as the object of research for explorers. ${ }^{93}$ Following Rousseau, literature in general became enthusiastic about landscape descriptions; on top of that, there was the contemporary trend of literary exoticism, which expressed itself, among other ways, in the portrayal of the luxuriant vegetation of the tropics and other unfamiliar displays of nature. But at the same time, the Caribbean archipelago was a destination for geographic and other scientific expeditions exploring the flora, fauna, geological features, and suchlike.

A closer look, however, reveals that these two realms can by no means be examined in such isolation from each other as it might at first appear. There were numerous areas of cross-fertilization and reciprocal transfers, transfer processes that decisively shaped both genres in the nineteenth century. In the foreword to his novel Eugène de Cerceil ou les Caraïbes, J.H.J. Coussin refers to the aesthetic value of the landscape descriptions in the scientific works written by explorers, who helped to initiate the development towards a lyrical enjoyment and literary processing of nature:

The passion for natural history that became so strong in late-eighteenth-century France also served to increase the taste for the picturesque. Botanists and geologists, especially, visited deserts that were unknown to the whole world. ... The imagination of these travelers, friends of the sciences, was able to find in these hitherto unexplored sites a charm that several of them succeeded in bringing into their writing. Truly sensitive men were fascinated by this kind of beauty, which had been neglected for so long; the others pretended to love it, because it was fashionable; and from that time on, it was the custom of almost all travelers who aspired to the reputation of being men of taste to turn aside from their path to go admire precipices, waterfalls, caves, and desert scenes of which in the past no one would have ever thought to dream. (Coussin I:iv-v) ${ }^{94}$

93 I am grateful to Marion Schotsch for crucial conceptual suggestions and research for this and the following section.

94 "La passion de l'histoire naturelle qui se développa avec force en France vers la fin du $18^{\mathrm{e}}$ siècle, servit aussi à augmenter le goût du pittoresque. Les botanistes, les géologues surtout visitèrent des déserts ignorés de tout le monde. ... L'imagination de ces voyageurs, amis des sciences, sut apercevoir dans ces sites jusqu'alors inexplorés, un charme que plusieurs d'entre'eux réussirent à faire passer dans leurs écrits. Les hommes véritablement sensibles se passionnèrent pour ce genre de beautés si longtemps négligées; les autres firent semblant de les aimer parce que c'étoit la mode; et depuis lors, ce fut l'usage de presque tous les voyageurs, qui aspiroient à la réputation d'hommes de goût, de se détourner de leur chemin, pour aller ad- 
The contagion between the literary and the scientific contemplation of nature took place just as much in the opposite direction as well. Contemporary novels very often included long passages referring to natural science and sometimes sounding like treatises. In the novel Les amours de Zémédare et Carina (1806), Prévost de Sansac uses a visit by natural researchers as the excuse for a digression about the geological composition of the island of Martinique:

\begin{abstract}
After they left Mr. le J ${ }^{\star \star \star}$, our travelers went to visit Mount Pelée; this mountain, its surroundings, and in fact the entire island presents undeniable vestiges of volcanic eruptions. Nowhere on Martinique does one see a primitive mountain, their formation only dates, if one judges by the materials composing them, from the era of the violent convulsions of nature, long after the creation of the world. „I establish this opinion,“ says Mr. Tamony, „based on the very small quantity of topsoil that covers them and the fact that their interior does not contain any of those immense blocks of hard rock that one finds in almost all mountains in other parts of the world. The only granite to be found consists of very small, rolled pieces, and only at the edge of the ocean, which could make one think that it had been brought there." These naturalists had observed that in some places, the layer of topsoil was barely more than six inches thick, and that it is followed by a layer of pumice stone about a foot thick; that after that, there is another layer of topsoil, eight to ten inches high and stripped of any vegetative capacity, which was certainly removed from it by the action of the blazing pumice stones that suddenly covered it during the last eruption. Then there is a second layer of pumice stones that came after that, which was followed by a bed of loamy soil, dyed by red iron oxide; underneath that, one found true pozzolana, which the inhabitants of Saint-Pierre found it useful to use in building. Mr. Tamony complained of not having been able to collect more than a very small amount of important minerals: flood basalt, calcinated hornfels containing pieces of feldspar, some volcanic garnets, pyroxene, and the substances that one finds the most often in volcanic countries. He had some very light pumice stones, all of whose interstices were filled with mica flakes of the most beautiful golden color. He showed Mrs. Sainprale some ferruginous sands of various qualities, containing some very pretty microscopic crystals; but the purest and finest, he said, can be found in abundance along the seashore, in the town where they have the boat building. He also had some beautiful pieces of ocher of all colors $(91 \mathrm{f} .)^{95}$
\end{abstract}

mirer des précipices, des cascades, des grottes, des scènes de désert enfin, auxquelles personne ne s'avisoit de songer autrefois."

95 "De chez M. le J ${ }^{\star \star \star, ~ n o s ~ v o y a g e u r s ~ f u r e n t ~ v i s i t e r ~ l a ~ m o n t a g n e ~ P e l e ́ e ; ~ c e t t e ~ m o n t a g n e, ~ s e s ~}$ environs et même toute l'île entière, offre des vestiges irrécusables d'éruptions de volcans. On ne voit nulle part, à la Martinique, de montagne primitive, elles ne datent leur formation, si on en juge par les matières qui les composent, que de l'époque de violentes convulsions de la nature, très postérieures à la création du monde. 'J'établis cette opinion, dit M. Tamony, sur la très petite quantité de terre végétale qui les recouvre, et que leur intérieur ne contient aucun de ces blocs immenses de pierre dure et autres, qu'on retrouve dans presque toutes celles des autres parties de la terre. Le granit ne se trouve qu'en très petits morceaux roulés, et sur le bord de la mer seulement, ce qui pourrait faire croire qu'il y a été apporté.' Ces naturalistes avaient observé que 
The passage I have cited here in detail shows that the elements of the scientific description of nature and of the fictional plot of the novel can barely be kept separate any more. The description of reality is transferred to the fictional project, producing an effect that Ottmar Ette ("Eine Literatur ohne festen Wohnsitz") describes as friction and which can be found particularly often in travelogues and biographies.

In the context of the Caribbean, however, it is not only descriptions of nature that are affected by the phenomenon of "friction"; it also extends to other realms of the scientific registration of the world, for example early ethnological studies, which will be more closely looked at in the next chapter, with the help of selected journals. At this point, I want to cite a further passage from Prévost de Sansac's novel as an example, a passage titled "Observations by the Priest of Gros Morne on How to Recognize Character through the Study of Physiognomies" (Observations du curé de Gros-Morne sur les moyens de reconnaître le caractère par l'étude des physionomies) and in which physiognomy and the study of temperament are entered into in depth. Many contemporary geographers and ethnologists took for granted that conclusions about the people's character could be drawn from the shape of the face and head:

Physiognomy often has its home in the eyes; one rarely sees someone with black eyes who is habitually indolent and lazy, those who are usually have blue eyes; with blue eyes, tenderness is more energetic; very clear eyes are rarely lacking in order and clarity in the spirit; confident eyes do not love anything, no matter what they might say; damp eyes are very loving, and wide-open eyes love everything-Eyes whose liqueurs are blurred inspire mistrust; slitted eyes promise little spirit; eyes that are large and shining tell me that they are animated by a healthy soul; those that start out of the head make one fear stupidity and malice; deep-set eyes sometimes belong to an envious and treacherous man; if they are

dans quelques endroits, la couche de terre végétale n'avait guère plus de six pouces d'épaisseur, qu'elle est suivie d'une couche de pierre-ponce épaisse d'un pied environ; qu'après celle-ci, vient une autre couche de terre végétale, haute de huit à dix pouces, dénuée de toute faculté végétative, qui lui a sans doute été enlevée par l'action des pierres-ponces embrasées qui la couvrirent tout à coup lors de la dernière éruption. Une seconde couche de pierres-ponces venait encore après, et elle était suivie par un lit de terre argileuse teinte par l'oxide rouge de fer; audessous on trouvait de la vraie pouzzolane, que les habitants de Saint-Pierre emploient utilement pour bâtir. M. Tamony se plaignit de n'avoir ramassé que très peu de minéraux importants; des trapps, des cornéennes calcinées qui contenaient des morceaux de feld-spath, quelques grenats de volcans, des pyroxènes et les substances que l'on trouve le plus fréquemment dans les pays de volcans. Il avait des pierres-ponces extrêmement légères, dont tous les interstices étaient remplis par des paillettes de mica de la plus belle couleur d'or. Il fit voir à Mme Sainprale des sables ferrugineux de diverses qualités qui contenaient de très jolis cristaux microscopiques; mais le plus pur et le plus fin se trouve, dit-il, en abondance sur le rivage de la mer, au bourg de la case des navires. Il avait aussi de très beaux morceaux docre de toutes les couleurs.” 
too close to each other, if they make the gaze fierce, then one should expect cruelty; the eyes of the distracted man look at you and do not see you, they imitate the preoccupation of the studious man while the mind thinks of nothing. $(101)^{96}$

\section{III.9 Digression: Sugar and Skin Color between Metropolis and Colonial Projection}

There are two basic pillars to the nineteenth century's (anti-)slavery debates that reach back into the eighteenth century and which have to date received hardly any attention in studies of the literary presentation of these debates; these two pillars are sugar and skin color. ${ }^{97}$ In the context of cultural studies debates over "things" as practical social strategies of appropriation (Ecker and Scholz; Latour; Daston), it is worth taking a look at these basic pillars and, especially, at the connection between them in the fragile in-between space of Caribbean experiences and attributions of identity. Travelogues discursivized and (re-)contextualized the circulation of novel goods and things that were foreign to Europeans and carried it to the European metropolises (see Leonard and Pretel). Two travelogues in French, in which the knowledge of foreign things intersects in a very concentrated way, were particularly influential: Jean-Baptiste Labat's Nouveau voyage aux isles de l'Amérique (New voyage to the islands of America) (1722) und Guillaume-Thomas François Raynal's Histoire philosophique et politique des établissements et du commerce des européens dans les deux Indes (Philosophical and political history of the establishments and trade of Europeans in the two Indias) (1770). Using an analysis of these two texts as a starting point, in this digression I will examine the chronological development of cultural forms of rep-

96 "Le siège de la physionomie se trouve fréquemment dans les yeux; on voit rarement quelqu'un avec des yeux noirs être indolent et paresseux par habitude, ceux qui le sont ont les yeux bleus; chez les yeux bleus la tendresse est plus énergique; des yeux bien nets manquent rarement d'ordre et de netteté dans l'esprit; les yeux certains n'aiment rien, quoi qu'ils puissent dire; les yeux humides aiment beaucoup, et les yeux fort ouverts aiment tout - Les yeux dont les liqueurs sont brouillées inspirent de ta défiance; les yeux bridés promettent peu d'esprit; des yeux bien fendus et brillants me disent qu'ils sont animés par une âme saine; ceux qui sortent de la tête font craindre la bêtise et la méchanceté; les yeux enfoncés appartiennent quelquefois à un homme envieux et perfide; s'ils sont trop rapprochés l'un de l'autre, s'ils rendent le regard farouche, on doit s'attendre à de la cruauté; les yeux de l'homme distrait vous fixent et ne vous voient pas, ils imitent la préoccupation de l'homme studieux, tandis que l'esprit ne songe à rien.”

97 An exception is Boren, who also includes missionary Christian theology in his analysis. For the following remarks cf. Müller "Vom 'Genuß der Dinge, die wir so weit herholen ....”. 
resentation of sugar and skin color as "things" into the middle of the nineteenth century. To what extent are the discourses for and against slavery connected to the exotic resource of sugar, as a consumer good, and to skin color as an exclusionary strategy of appropriation, in Labat's and Rayal's depictions? Looking at Labat's ${ }^{98}$ major work will reveal strategies with which foreign things are made present, in this case the way in which sugar is presented as a local medium of exchange. It refers, in particular, to the conversion of basic foodstuffs and other imported goods into sugar:

In addition, our house was in debt to the tune of nearly seven hundred thousand pounds of sugar and had no credit anymore: these debts had been contracted by the poor housekeeping of the monks who had mismanaged their affairs, by the exorbitant spending of the priests who took whatever they wanted from the merchants and paid them with a sugar note, which was at that time the common currency of the islands, to be drawn on the plantation. ... This loss kept us from producing the quantity of sugar that we would have been able to produce. ... Besides, it was only raw sugar, disparaged for its poor quality, and which the war had reduced to such a low price that a hundredweight was only worth fifty or sixty sols, whereas food and other commodities from France were at an excessive price. A barrel of flour cost fifteen hundred pounds of sugar; a barrel of salted beef the same; a barrel of bacon two thousand five hundred pounds; a wine keg cost three thousand pounds and sometimes more; all the sugar that we could produce added up to barely thirty thousand pounds, on which we had to maintain the Negroes, the livestock, the mill, and the other expenses of a plantation and feed the monks who were there. (Labat [1722] I:114-16) ${ }^{99}$

98 Jean-Baptiste Labat (Paris, 1663-1738) entered the Dominican order in 1684 and set out as a missionary to the West Indies in 1694. There he owned a plantation where he kept slaves and burned rum. Later, he was named as the general procurator for his order's mission in the East Indies, and from there he returned to Europe in 1705. His travelogues from the Antilles are very vividly written and were highly popular in Europe. His six-volume work Nouveau voyage aux isles de l'Amérique was published in Paris in 1722.

99 “D’ailleurs notre maison était endettée de près de sept cent mille livres de sucre et n'avait plus aucun crédit; ces dettes avaient été contractées par la mauvaise économie des religieux qui avaient mal gouverné leurs affaires, par les dépenses exorbitantes des curés qui prenaient chez les marchands tout ce qui leur plaisait et les payaient avec un billet de sucre qui était en ce temps-là la monnaie courante des îles à prendre sur l'habitation. ... Cette perte nous empêchait de faire la quantité de sucre qu'on aurait pu faire. ... D'ailleurs ce n'était que du sucre brut, décrié pour sa mauvaise qualité, et que la guerre avait réduit à si bas prix, que le cent ne valait que cinquante ou soixante sols, pendant que les vivres et les autres denrées de France étaient à un prix excessif. Le baril de farine coûtait quinze cent livres de sucre; le baril de bœuf salé autant; le baril de lard deux mille cinq cent livres; la barrique de vin trois mille livres et souvent davantage; tout le sucre qu'on pouvait fabriquer chez nous allait à peine à cent trente mille livres, sur quoi il fallait entretenir les Nègres, les bestiaux, le moulin et les autres dépenses d'une habitation et nourrir les religieux qui y étaient." 
Thanks to sugar, the French colonies of the Caribbean established themselves as productive spaces of consumption. Trading establishments expanded and exports to Europe, in particular, flourished.

This town has grown a great deal because the considerable quantity of cocoa, sugar, and cotton that is produced in these quarters, and particularly on Gros Morne peak, has attracted a large number of merchants and a quantity of ships, especially from Nantes, which make commerce flourish there and which find a guaranteed and prompt market for all the merchandise that they bring there from Europe. (I:336) ${ }^{100}$

The sugar trade between the Caribbean colonies and the French metropolis is staged in Labat as a strategy of creating presence. He gives the inhabitants of the island the advice that they should only exchange sugar for money, preferably on the spot, in the colonies, but to always use it themselves as a means of payment:

The last piece of advice that I would give a resident is to sell his sugars and his other commodities for hard cash or for well-backed promissory notes, and not to pay for what he buys with anything other than sugar or some other thing originating from his plantation. This is the secret to enriching oneself. ... It is even better to sell to the islands for cash or for promissory notes than to send goods to France, because the freight charges, the entry tariffs, the tares, the barrels, the companies' claims, the storage fees, and the commissions take away most of the profit and sometimes even part of the capital, leaving the owner for a long time in a state of anxiety over the fate of his goods. (Labat [1742] IV:221 ff. ${ }^{101}$

Labat also describes sugar, as a "thing," in relationship to French culture, of which it is a part in spite of its foreignness. In the Nouveau voyage aux isles de l'Amérique, it is presented not just as the dominant product of the Antilles, simultaneously a commodity and a means of payment, but also as, for European

100 “Ce bourg s'est beaucoup augmenté, parce que la quantité considérable de cacao, de sucre, de coton que l'on fabrique dans ces quartiers-là, et surtout au gros morne, y ont attiré bon nombre de marchands et quantité de vaisseaux, particulièrement de ceux de Nantes qui y font fleurir le commerce et qui trouvent un débit assuré et prompt de toutes les marchandises qu'ils y apportent d'Europe."

101 "Le dernier avis que j'aie à donner à un habitant est de vendre ses sucres et ses autres denrées en argent comptant ou en lettres de change bien assurées, et de ne payer ce qu'il achète qu'en sucre ou autre chose provenant du fond de son habitation. C'est le secret de s'enrichir. ... Il vaut mieux encore vendre comptant aux îles ou en lettres de change que d'envoyer les effets en France, parce que le fret, les entrées, les tares, les barriques, les droits des Compagnies, le magasinage, les avanies et les commissions emportent le plus clair du profit et quelquefois même une partie du capital et laissent le propriétaire pendant longtemps dans l'anxiété du sort de ses marchandises." 
readers, a kind of metonymic stand-in for the Caribbean colonies: their economic importance and position in the world is contained in sugar, as is their otherness, which is particularly expressed in the linkage of sugar and skin color.

A further example of Labat making foreign things present is the reification of skin color, inasmuch as it is skin color that determines the amount of head tax that must be paid to the king:

The king's dominion in the islands consists of the right to impose a head tax which all white men and free, indentured, or enslaved black men pay from the age of fourteen years until sixty. This entitlement is for one hundred pounds of actual raw sugar per year, for those who produce it, and six francs for those who do not. It is the masters who pay for their indentured or enslaved servants. One pays another one percent of all the sugar that one delivers for the right to weigh it oneself. ... All of the white Creoles, that is those born in the islands, and generally all the white women, are exempt from the head tax as well as slaves, servants, or indentured servants of the clergy, of the former lords, owners of the islands, and their representatives. (Labat [1722] I:242ff.) $)^{102}$

Sugar and skin color, as foreign things, remain in constant relation with each other, as the tax, which is determined along skin color lines, is paid by the plantation owners in sugar. Labat describes the two as inseparably connected within the universe of plantation slavery: "it was absolutely necessary to have slaves, unless one wanted to discontinue the work of the sugar factories" (Labat [1742] IV:419). ${ }^{103}$ Even in the slave trade itself skin color becomes a criterion, that is to say it undergoes a reification. In Africa one paid in bars of crude iron, guns, powder, and cowries from the Maldives (IV:428ff.), ${ }^{104}$ while in the An-

102 "Le domaine du roi dans les îles consiste dans le droit de capitation que tous les hommes blancs ou noirs libres, engagés ou esclaves payent depuis l'âge de quatorze ans jusques à soixante. Ce droit est de cent livres de sucre brut effectif par an, pour ceux qui en font ou de six francs pour ceux qui n'en font point. Ce sont les maîtres qui payent pour leurs domestiques engagés ou esclaves. On paye encore un pour cent de tout le sucre qu'on livre pour avoir le droit de le peser chez soi. ... Tous les blancs créoles c'est-à-dire, nés dans les îles, et généralement toutes les femmes blanches sont exemptes du droit de capitation aussi bien que les esclaves, serviteurs ou engagés des religieux ou des anciens seigneurs, propriétaires des îles et leurs représentants."

103 "il était absolument nécessaire d'avoir des esclaves, à moins de discontinuer le travail de la sucrerie." Cf. also Labat's description of the blacks' huts on a hill behind the sugar factory (Labat [1722] I:114).

104 "they are paid in bars of iron, rifles, powder, bullets, canvases, paper, light fabrics and other goods, and especially in 'bouges,' shells from the Maldive Islands that are used as common currency all along the coast" ("on les paye en barres de fer, fusils, poudre, balles, toiles, papier, étoffes légères et autres marchandises, et surtout en bouges, des coquilles des îles Maldives qui servent de monnaie courante dans toute la côte"). 
tilles, on the other hand, it was sugar that was used as a means of exchange: "I bought twelve [slaves], who cost me five thousand seven hundred francs, which I had to pay in raw sugar" (IV:419). ${ }^{105}$

Sugar is very frequently perceived in relation to skin color and is, as a result, exotic, foreign, and near all at the same time. On the one hand, it is a coveted commodity; on the other hand it is necessarily bound up with slavery and therefore with distinctions between colors of skin. In Labat's Nouveau voyage it is constantly shown that, given the Western privileging of spirit over matter, sugar can at first arouse the appearance of immediacy because the separation of subject and object, of the perceiving I and the sensual world of things, causes the things that are located on the object side, as distinct from consciousness, to appear to be moved, governed, and appropriated by consciousness. This almost paradoxical relationship of radical division between person and thing on the one hand and their simultaneous dependency on each other in all realms of the cultural and social production of meaning is constitutive of the representation of sugar in Labat (cf. Ecker and Scholz 10).

Although the primary mode of existence for things in a consumer society is as goods, these attributions of value are also relevant beyond the discourse of goods. The reduction of value to an exchange value is only one aspect of the ways in which things acquire meaning, because in addition to their material value there can be a symbolic or ideal value that is often the dominant force in giving them meaning, both personal and collective (cf. Ecker and Scholz 12). It is worth taking a look here at the relationship between skin color and sugar as a condition for the Haitian Revolution. Even though the Haitian Revolution could not have been anticipated from a cultural historical standpoint, Guillaume-Thomas François Raynal's travelogue communicates a way of reading eighteenth-century Caribbean constellations that is steeped in ambivalence and prepares the ground for long-lasting categories of perception built on this ambivalence to assert themselves; in the year 1770, a six-volume work was published anonymously in Amsterdam under the title Histoire philosophique et politique des établissements et du commerce des Européens dans les deux Indes (Philosophical and political history of the establishments and business of the Europeans in the two Indias), which was disseminated and attracted attention throughout Europe. The following editions were expanded to include texts by several authors, the most famous of them being Diderot. His contributions were far more uncompromising in their anti-colonialism than the more moderated and

105 “j'en achetai douze [esclaves], qui me coûtèrent cinq mille sept cens francs, que je devois payer en Sucre brut.” 
conciliatory tones of the original text, written by Raynal. When the final version of the text appeared in 1780, this time under Raynal's name ("a kind of miniEncyclopédie of colonialism's political, intellectual, and social effects on Europe" [Pagden 118] ${ }^{106}$ ), it was banned by the censor. In "The Extinction of Difference," Anthony Pagden sums up the key findings on Raynal:

Raynal himself was a moderate reformer, a man who, as Frédéric Grimm put it, advocated positions that were "more in keeping with conventional politics than with justice." Later, in 1785, Raynal also wrote an Essai sur l'administration de St. Domingue (Essay on the administration of Saint-Domingue) in which, although he did suggest reforms, he espoused neither the liberation of the slaves nor the abolition of the slave trade. $(116)^{107}$

In this essay he expresses moral outrage, as many others also do, over skin color as a distinguishing feature and over the evil that follows from it, slavery, which he calls "the terrible right of the stronger" (le droit terrible du plus fort) (Raynal, Histoire philosophique 13), but he also claims that abolishing it would not be politically acceptable. For Raynal, slavery is a manifest evil, an absurdity, that as a social practice denies the human being the one inalienable right that is a person's own, namely "self-ownership" (propriété de soi) and therefore also denies "the specific character of a human being." For slavery, as the prominent abolitionist Frossard argued to the National Assembly in 1793, not only made humanity into a thing, in other words a commodity, but it also valued humans according to their physical strength, the very quality that is the least essential to human identity, thereby representing "the greatest insult to our nature" (Pagden 125). ${ }^{108}$

106 "eine Art Mini-Encyclopédie über die politischen, intellektuellen und gesellschaftlichen Auswirkungen des Kolonialismus auf Europa”.

107 "Raynal selbst war ein gemäßigter Reformer, ein Mann, der, wie es Frédéric Grimm formulierte, Auffassungen vertrat, die sich 'mehr mit herkömmlicher Politik als mit Gerechtigkeit vertrugen'. [...]. Später, im Jahre 1785, schrieb Raynal auch einen Essai sur l'administration de St. Domingue, in dem er zwar Reformen vorschlug, aber weder für die Freilassung der Sklaven noch für die Abschaffung des Sklavenhandels eintrat.” As Ottmar Ette sums up Raynal's position: "In spite of all of the contradictions and ambivalences that ... compromised the effectiveness of the Histoire des deux Indes, Raynal and his famous work were nevertheless the symbols of a liberation from colonial oppression." "“Allen Widersprüchen und Ambivalenzen, welche die Wirkung der Histoire des deux Indes [...] beeinträchtigten, zum Trotz, standen Raynal und sein bekanntes Werk doch symbolhaft für eine Befreiung aus kolonialer Unterdrückung.”) (Ette, "Figuren und Funktionen des Lesens" 590).

108 Condorcet, in his 1781 Réflexions sur l'esclavage des nègres (6ff.), also specifically pointed to the legal objectification of slaves: even a contract worker, who in some sense had sold himself into slavery, had really only sold the right to the use of his work and was, in his relationship to his master, bound by public rather than private law. The slave, on the other hand, was nothing 
Raynal and his co-authors of Histoire ... des deux Indes respond to this radical objectification of the African slaves by referring to skin color, which they recognize as the central justification for this inhuman treatment. In the manner of the late Enlightenment, they present skin color as a foreign thing that needs to be examined as a scientific object, freed from its old interpretive connections, and newly explained. Skin color is described as a value-free physiological phenomenon:

This color comes from a mucous substance that forms a kind of network between the epidermis and the skin. This substance, which is white in Europeans, brown in olive-skinned peoples, and dotted with reddish spots in blond or red-headed peoples, is blackish in the Negroes. (Raynal, Histoire philosophique VI:52 ff.) ${ }^{109}$

Science, they point out, has not yet found a clear explanation for the varying skin colors of humanity, because skin color is a complex thing: "Our organs are so weak, our resources so short, our studies so distracted, our life so agitated; and the object of our research is so vast!” (VI:58) ${ }^{110}$ Thus, the climate is often mentioned as an important factor influencing skin color, in connection with the thought that skin color might possibly change over a period of generations in a new environment:

The coloring of Negroes is the result of the climate, the air, the water, the foodstuffs of Guinea, and it changes when you take them to other countries. The children that they procreate in America are less black than those who gave birth to them. After each generation, the difference is more noticeable. It could be that after a number of generations one would no longer be able to distinguish the men who have come from Africa from those of the countries to which they had been transplanted. (VI:57) 111

but a legal matter (a res), exactly as in Roman law, and was therefore entirely dependent on the "whim of his master" (Pagden 126).

109 "Ce coloris vient d'une substance muqueuse, qui forme une espece de rézeau entre l'épiderme et la peau. Cette substance qui est blanche dans les Européens, brune chez les peuples olivâtres, parsemée de taches rougeâtres chez les peuples blonds ou roux, est noirâtre chez les negres."

110 "Nos organes sont si foibles, nos moyens si courts, nos études si distraites, notre vie si troublée; et l'objet de nos recherches si vaste!"

111 "Le coloris des nègres est l'effet du climat, de l'air, de l'eau, des alimens de la Guinée, c'est qu'il change lorsqu'on les conduit dans d'autres nations. Les enfans qu'ils procréent en Amérique sont moins noirs que ceux dont ils ont reçu le jour. Après chaque lignée, la différence est plus sensible. Il se pourroit, qu'après de nombreuses générations, on ne distinguât pas les hommes sortis d'Afrique, de ceux des pays où ils auroient été transplantés.” 
By no means could the dark coloring of the skin be traced back to any chemical processes of decay, because after all the physiological organization of the Negroes is "just as complete ... as in the whitest of human species" (aussi parfaite ... que dans l'espece d'hommes la plus blanche) (VI:54). The conventional essentializations of skin color, with their negative value judgments, are flatly rejected, as can also be seen from the ironic treatment of the religious discourses about the original sin of the Africans:

Theology, after having made a race of men guilty and unhappy through Adam's fault, now makes a race of men black to punish the fratricide of his son. It is from Cain that the Negroes are descended. If their father was an assassin, it must be admitted that his crime is being cruelly expiated by his children; and that the descendants of the peaceful Abel have thoroughly avenged the innocent blood of their father. (VI:53) ${ }^{112}$

Pagden points out that it is, paradoxically, the slave trade itself that ties together the two main themes of the Histoire des deux Indes, namely traveling/migration and trade. After the discovery of America, slavery, which until then had been a product of warfare, now became a branch of trade instead (130). And the Histoire looks just as critically at traveling and the circulation of foreign things and consumer goods that is bound up with it, sugar being the preeminent example:

Does our true happiness require us to enjoy the things that we fetch from so far away? ... Can the advantages it brings us in goods make up for the loss of the citizens who leave their fatherland and who perish either through illnesses that seize them while they are traveling or through the climate when they arrive? ... What firm bonds can tie us to a possession from which we are separated by an immeasurable space? (Raynal and Diderot $186-187)^{113}$

Diderot in particular, in the passages written by him in the Histoire des deux Indes, opposes the swelling stream of goods when he writes that the diversity and quantity of objects that are served to the spirit and the senses have splintered men's emotions and weakened the energies of all sensations (cf. Pagden

112 "La théologie, après avoir fait une race d'hommes coupables et malheureux par la faute d'Adam, fait une race d'hommes noirs, pour punir le fratricide de son fils. C'est de Caïn que sont descendus les negres. Si leur pere était assassin, il faut convenir que son crime est cruellement expié par ses enfants; et que les descendants du pacifique Abel ont bien vengé le sang innocent de leur père."

113 "Erfordert unser wahres Glück den Genuß der Dinge, die wir so weit herholen? ... Kann das, was er an Waren bezieht, mit Vorteil den Verlust der Bürger ersetzen, die sich von ihrem Vaterland entfernen, um entweder durch Krankheiten, die sie auf der Reise ergreifen, oder durch das Klima bei ihrer Ankunft umzukommen? ... Durch welche festen Bande kann mit uns eine Besitzung, von welcher uns ein unermeßlicher Raum trennt, verbunden sein?” 
$134 \mathrm{ff}$.). The voyages and the long-lasting sea journeys, he wrote, had impoverished the morals and imagination of all Europeans and, what was worse, had increased their tolerance for the suffering of others, represented by the lasting symbol of the enslaved African. Diderot was, for this reason, also firmly convinced that only a revolution, under the leadership of a new "black Spartacus," could hope to open the eyes of the European colonial world to the misdeed that it had committed-in retrospect, this sounds like an advance announcement of the Haitian revolutionary leader Toussaint Louverture (135).

Considering sugar and skin color as things reveals a new perspective on cultural forms of representation from and about the Caribbean: by focusing on the two pillars represented by sugar and skin color, we can read the Caribbean as a place in which the American culture of presence and the European culture of the senses collide. Sugar and skin color are protagonists in these continental encounters. While sugar functions above all as a medium of exchange and a consumer good in Labat, in Raynal sugar and skin color, in the context of a prehistory of the Haitian Revolution, function as the constitutive pillars of the constitution of the subject in the context of the (anti-)slavery debate. Following the Haitian Revolution, we can determine that in literary as well as in ethnological representations of sugar, it always acts as a counterbalance to the French metropolis's concept of culture. In Paris, the colonial center, it is impossible for sugar as a thing to escape the standards of commodity valuation: as soon as sugar is transferred from the Caribbean to Europe, it belongs there to a new economy of meaning and value and its original meanings are pushed into the background (Ecker and Scholz 12).

The look we have taken at Labat and Raynal has, however, also shown that sugar and skin color always take on a life of their own. As Susanne Scholz has shown in relation to objects in modernity (Ecker and Scholz 11ff.), sugar and skin color also produce a surplus of meaning in whatever environment they are in-whether it is the Caribbean or Paris-that leads to their constantly being revaluated, restructured, and inserted into new meanings or to their producing new meanings. Sugar and skin color function as projections or as alter egos, whether of a colonial master or of a chronicler (in other words, of those who own them or desire them), and yet they produce a surplus of materiality or tangibility that is not absorbed in the service of the subject (11). This can be seen, for example, in the reification of skin color in the nineteenth century, in the context of new Caribbean ethnic mixtures as a utopian project, in a quotation from the Revue des Colonies that circulated from 1834 to 1842 and will be discussed in greater detail in the next chapter: 
From these whites, from these blacks, from these reds, there will be founded a mixed race of Europeans, Africans, and Americans, which within several generations and through various interminglings will arrive, by way of brown, caramel, plum-dear sir, orange-ish-at a pale yellow, lightly coppered. All of these singularities, all these marvels of civilization that elevate and interest our heart and our spirit, are more or less near. (Revue des Colonies, July 1836, 20 ff. $)^{114}$

Here (dark) skin color, as a foreign thing that made the separation between European colonial masters and African slaves obvious to eighteenth- and nineteenthcentury Europeans, deploys its potential to overcome this very distinction and dissolve the hierarchy that is attached to it. In the color-rapture of all the possible shades of skin the aesthetic "singularities" show the way to the "marvel of civilization," understood both ethically and ethnically, of a Caribbean society without racial differences.

114 "De ces blancs, de ces noirs, de ces rouges, il se fondera une race mélangée d’Européens, d'Africains et d'Américains, qui en quelques générations et au travers des croisements divers, arrivera, par le brun, le carmélite, le prune-monsieur, l'orangé, à un jaune pâle, légèrement cuivré. Toutes ces singularités, toutes ces merveilles de civilisation qui élèvent et intéressent notre cœur et notre esprit, sont plus ou moins prochaines.” 